\title{
Domestic Competition, Cyclical Fluctuations, and Long-Run Growth in Hong Kong SAR
}

Eric Zitzewitz 


\title{
IMF Working Paper
}

Asia and Pacific Department

\section{Domestic Competition, Cyclical Fluctuations, and Long-Run Growth in Hong Kong SAR}

\author{
Prepared by Eric Zitzewitz ${ }^{1}$
}

Authorized for distribution by Ranjit Teja

August 2000

\begin{abstract}
The views expressed in this Working Paper are those of the author(s) and do not necessarily represent those of the IMF or IMF policy. Working Papers describe research in progress by the author(s) and are published to elicit comments and to further debate.
\end{abstract}

This paper provides an empirical assessment of the degree of competition in Hong Kong SAR using industry-level data. Although due to data limitations only approximate measures of competitiveness can be estimated, the results do suggest that Hong Kong SAR is as competitive as a typical OECD economy. The dramatic shift of the economy toward services over the last decade has also made it slightly less compctitive on average. Imperfect competition is not leading to counter-cyclical markups and slower price adjustment as some theories predict, however, since markups are more pro-cyclical than in OECD countries. Lastly, markups are sufficiently imperfectly competitive in both Hong Kong SAR and the OECD to significantly downwardly bias growth accounting estimates of total factor productivity in Asian NICs vis-à-vis OECD countries.

JEL Classification Numbers:E31, E32, L13, L16

Keywords: Markups, competitiveness, cyclical fluctuations, growth

Author's E-Mail Address: ericz@mit.edu

\footnotetext{
${ }^{1}$ This paper was written when the author was a summer intern in the Asia and Pacific Department in 1999. The author would like to thank Jahangir Aziz and David J. Robinson for helpful suggestions and comments and the Hong Kong Monetary Authority and Census and Statistics Department for providing the Hong Kong SAR industry-level data used in the paper.
} 


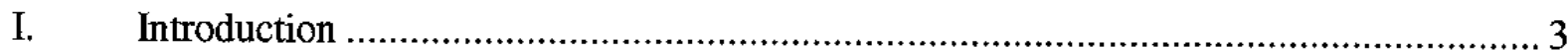

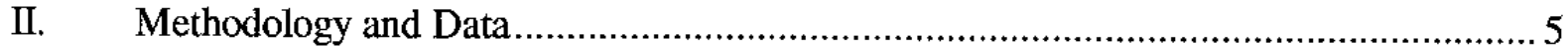

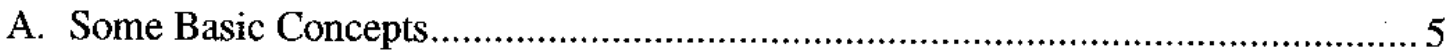

B. Estimation Techniques ............................................................................ 7

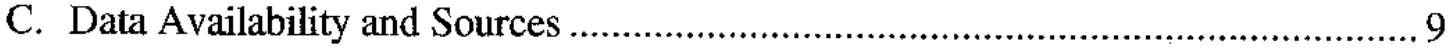

III. How Competitive is Hong Kong SAR? ........................................................... 10

IV. Evolution of Competition in the Hong Kong SAR Economy .................................. 17

V. Cyclicality of Markups and Adjustment in Hong Kong SAR .................................2 23

VI. Implications for the Measurement of the TFP Growth........................................... 26

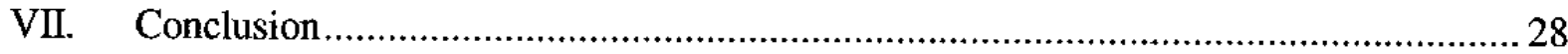

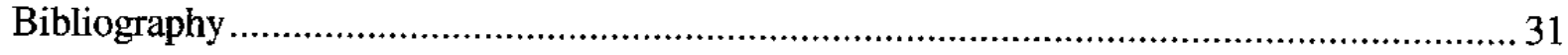

Tables

1. Price-Average Cost Margins, 1986-97 Average.................................................. 12

2. OLS and IV Estimation of P-MC Markups Using the Modified Roeger

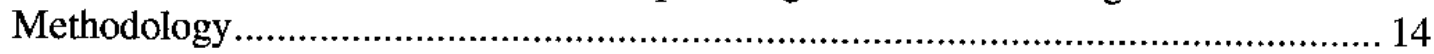

3. Hong Kong SAR's Relative Rank on Different Measures of Competition.................. 15

4. Four Methodologies for Measuring P-MC Margins................................................ 18

5. Correlation of P-MC Margin Estimates Using Different Methodologies .................... 19

6. Trend in Price-Average Cost Margins .................................................................... 21

7. Effect of Industry Mix Shift on Margin Levels and Cyclicality................................ 22

8. Cyclicality of Price-Average Cost Margins ........................................................... 25

9. Bias to Measured TFP Implied by the Estimated Markups ....................................... 27

Figures

1. Industry-by-Industry Comparison of Intensity of Competition in

Hong Kong SAR Versus the OECD................................................................. 11

2. Comparison of Intensity of Competition Across Industries in Hong Kong SAR ........ 16

3. PA-C Margins in Manufacturing and Service Sectors, 1986-87 ................................ 30

Box

1. Price Adjustment in Hong Kong SAR and OECD Countries .................................. 4

Appendix

I. Derivation of P-MC Measurement Methodologies

Annex Tables

1. Results for Detailed Hong Kong SAR Industries................................................. 36

2. Shift in Industry mix in Hong Kong SAR, 1986-97 ............................................ 37

3. Average P-AC Margins by Country ….............................................................. 38

4. Cyclicality and Trend of P-AC Margins, 1986-97 .................................................. 39

5. Average P-MC Margins for Manufacturing and Services ................................... 40 


\section{INTRODUCTION}

Hong Kong SAR has traditionally been viewed as having highly competitive product and factor markets. Competition has been credited not only with contributing to high long-run output and productivity growth but also with providing a supporting framework for rapid price adjustment in response to economic shocks while maintaining a fixed exchange rate. Given the importance of competition, surprisingly little systematic empirical work has been done in evaluating the degree of competition in Hong Kong SAR's industries. While prices have historically adjusted much more rapidly in response to shocks in Hong Kong SAR than in OECD economies (Box 1), many observers in recent years have raised questions about the degree of domestic competition, particularly in light of the economy becoming increasingly dominated by service industries. ${ }^{2}$

This chapter estimates quantitative, industry-level measures of the intensity of competition and compares them both across industries and between Hong Kong SAR and OECD countries. These measures are also used to evaluate whether degree of competition has changed in the last decade and how markup cyclicality affects the adjustment process. The chapter has four main findings:

- Hong Kong SAR is neither significantly more nor significantly less competitive than the average OECD country. Given its fixed exchange rate and exposure to external shocks, however, Hong Kong SAR may actually need more competition than other countries. Further investigation of competition in specific sectors may therefore be justified. Most of the measures in this paper suggest that food processing, nonmetallic minerals, real estate and transportation are less competitive than the average industry, while construction, restaurants and hotels, and textiles and apparel appear to be among the most competitive.

- Competition in Hong Kong SAR has become slightly less intense over the last decade as the economy has rapidly shifted out of manufacturing.

- Markups are more pro-cyclical in Hong Kong SAR than in the average OECD country in the service sector, which now accounts for over 90 percent of GDP. The shift to services has also made economy-average markups more pro-cyclical. This should be contributing to faster-than-average price adjustment in Hong Kong SAR.

\footnotetext{
${ }^{2}$ The Hong Kong SAR Consumer Council has issued reports, since 1992, questioning the competition in several service industries, including broadcast television, supermarket retailing, heating fuel, lift maintenance, residential property development, and retail banking.
} 


\section{Box 1. Price Adjustment in Hong Kong SAR and OECD Countries}

The rapid adjustment of prices in Hong Kong SAR in the past is illustrated by the slope of the Phillips Curve, i.e., the effect of the level of the unemployment rate on the acceleration of the inflation rate. A single point increase in the unemployment rate has historically been associated with a deceleration of 0.41 points in inflation in Hong Kong SAR, compared with 0.05 points for the average country in our OECD sample. The conclusion that price adjustment has been extremely rapid in Hong Kong SAR is robust to controlling for external price shocks (represented by the acceleration of price inflation for imports, exports, or oil prices) and unemployment hysterisis effects (handled by including lagged unemployment in the regression equation).

Phillips Curve in Hong Kong SAR and OECD, 1973-98

Dependent Variable: Change in Year-on-Year Rate of CPI Inflation

\begin{tabular}{lccc}
\hline Controls & & & \\
Oil, import, and export price inflation & $\ldots$ & $\mathrm{X}$ & $\mathrm{X}$ \\
Lagged unemployment & $\ldots$ & $\ldots$ & $\mathrm{X}$ \\
Hong Kong SAR & -0.41 & -0.33 & -0.42 \\
& $(0.10)$ & $(0.09)$ & $(0.12)$ \\
Fourteen OECD Countries & -0.05 & -0.04 & -0.21 \\
& $(0.01)$ & $(0.01)$ & $(0.02)$ \\
Japan & -0.32 & -0.15 & -1.51 \\
& $(0.19)$ & $(0.17)$ & $(0.45)$ \\
United States & -0.19 & -0.11 & -0.21 \\
& $(0.03)$ & $(0.03)$ & $(0.05)$ \\
Canada & -0.08 & -0.07 & -0.20 \\
& $(0.02)$ & $(0.02)$ & $(0.05)$ \\
United Kingdom & -0.07 & -0.06 & -0.41 \\
& $(0.03)$ & $(0.03)$ & $(0.09)$ \\
Italy & -0.05 & -0.04 & -0.07 \\
& $(0.04)$ & $(0.04)$ & $(0.18)$ \\
France & -0.04 & -0.04 & -0.17 \\
Germany & $(0.01)$ & $(0.01)$ & $(0.09)$ \\
& -0.02 & -0.02 & -0.18 \\
& $(0.01)$ & $(0.01)$ & $(0.06)$ \\
\hline
\end{tabular}

Note: Regressions use quarterly data. Lagged unemployment is lagged by 4 quarters. Regressions are estimated using OLS and are not intended to be a prediction of the effect of unemployment on the acceleration of inflation, but rather a measure of their correlation and relative variance. Standard errors are in parentheses. 
- Market imperfections in both Hong Kong SAR and the OECD cause labor shares from national accounts data to understate the contribution of labor in output growth. Using an underestimated labor share downwardly biases measured total factor productivity (TFP) growth for countries with rising capital-labor ratios, for example, the Asian NIEs. Correcting this bias increases the contribution of TFP to growth in Hong Kong SAR. Moreover, such corrections to the growth accounting methodology could increase the productivity growth of all Asian Newly Industrialized Economies (NIEs) relative to OECD countries.

The remainder of the chapter is organized as follows. The next section discusses various methodologies and data used for measuring competition. The data in Hong Kong SAR is limited along two key dimensions, and thus several imperfect measures of competition are experimented with. The third section compares the level of the intensity of competition in Hong Kong SAR with that of OECD, while the fourth section examines how the intensity of competition in Hong Kong SAR has changed over time. The fifth section compares the cyclicality of markups in Hong Kong SAR and the OECD and discusses the implications for the adjustment process. A final section examines the implications of these findings about markups for the measurement of total factor productivity and thus for long-run growth in Hong Kong SAR.

\section{METhodology AND DATA}

\section{A. Some Basic Concepts}

Under Cournot competition, a profit maximizing firm sets its quantity such that:

$$
(P-M C) / P=\left(1 / \varepsilon_{d}\right) / n_{e f f} \quad P=\varepsilon_{d} \cdot n_{e f f} /\left(\varepsilon_{d} \cdot n_{e f f}-1\right) \cdot M C
$$

where $P$ is the price of the good, $M C$ is its marginal cost, $\varepsilon_{d}$ is the market elasticity of demand and $n_{\text {eff }}$ is the effective number of firms in the market, which is equal to one if firms are perfectly colluding and the actual number of firms if they are behaving noncooperatively. Note that higher markups do not necessarily imply less competition; they may also be due to lower demand elasticity. If it is assumed that the elasticity of demand for the output of a given sector is constant across countries, then a cross-country comparison of markups can reveal differences in competition. Comparisons of markups across sectors within a country can be more problematic, however, since demand elasticities can be quite different across sectors.

There are several theories that predict that markups will vary with the business cycle. In the two most popular--Rotemburg and Saloner (1986) and Green and Porter (1984) - markups vary because the ability of firms to collude, and thus $n_{\text {eff }}$, varies with the business cycle. In the Rotemburg and Saloner model, collusion is harder to sustain in booms because the benefits of cheating are proportional to current demand but the benefits of maintaining collusion are 
proportional to long-run demand. Sustainable markups are therefore counter-cyclical. ${ }^{3}$ In Green and Porter, collusion is harder to sustain in recessions since firms misinterpret a fall in market demand as cheating and this leads to price wars and thus pro-cyclical markups, causing average markups to be pro-cyclical. ${ }^{4}$ Counter-cyclical markups appear to be more common empirically, at least in the United States. ${ }^{5}$

In order to measure the cyclicality of markups, consider the following relationship between price-marginal cost (P-MC) and price-average cost (P-AC) markups (Morrison, 1990):

$$
P / A C=(C U / R T S) \cdot(P / M C)
$$

where $C U$ is the capacity utilization of an industry (defined as the long-run minimum cost to produce the current quantity divided by the current total cost) and RTS is the long-run return to scale (defined as the ratio of marginal cost to minimum average cost). Since capacity utilization is usually strongly procyclical and returns to scale are roughly constant through the business cycle, P-AC markups can be pro-cyclical even when P-MC markups are countercyclical. This is in fact what the literature has found for the United States. ${ }^{6}$ If the variation of capacity utilization and returns to scale with the business cycle is similar across countries within a given sector, then more procyclical P-AC markups are in country, then less countercyclical are P-MC margins. ${ }^{7}$ Likewise, if the average level of capacity utilization and returns to scale are similar across countries, comparisons of the level of P-AC markups can be revealing about P-MC markups.

${ }^{3}$ The "price wars during booms" referred to in the title of Rotemburg and Saloner is actually a misnomer in that price wars do not occur in equilibrium in their model. Rather, the price on which firms collude is lowered during booms to reduce the temptation for cheating.

${ }^{4}$ In Green and Porter firms observe only their own demand. Low demand for a given firm can result from either cheating by another firm or a negative demand shock. In equilibrium, no firms cheat, but in order to sustain this equilibrium firms respond to negative demand shocks with a price war.

${ }^{5}$ Rotemburg and Woodford (1999).

${ }^{6}$ DHP (1986) found pro-cyclical P-AC margins, while Domowitz, Hubbard, and Petersen (1987) and Rotemberg and Woodford (1991) found countercyclical P-MC margins in U.S. manufacturing. Bils (1987) and Morrison (1990) found that the MC/AC ratio is strongly procyclical, which is consistent with these findings.

${ }^{7}$ The cyclical variation of capacity utilization depends importantly on adjustment costs. One might expect adjustment costs to be lower in Hong Kong SAR than in the OECD because of lower firing costs or the use of less capital-intensive technologies. Less cyclical capacity utilization would cause P-MC margin cyclicality to more closely approximate P-AC margin cyclicality in Hong Kong SAR than in the OECD. 


\section{B. Estimation Techniques}

Three broad approaches have been taken to estimating P-AC and P-MC markups and margins: ${ }^{8}$ direct measurement of P-AC margins, estimation of marginal cost by instrumenting for output, and estimating P/MC, CU, and RTS using a structural model (Morrison, 1990). In this paper, both of the first two methods will be used. The third method is more desirable, but is impossible for Hong Kong SAR given the data available.?

- $\quad$ Direct measurement of P-AC. Domowitz, Hubbard, and Petersen (DHP) (1986) directly measured price and average variable cost using census data. This approach is the most straightforward and allows one to calculate an independent measure of the $\mathrm{P}$-AC margin in each year, allowing one to estimate margin cyclicality even with short time series. Drawbacks of this approach include the difficulty of measuring the economic cost of capital services and the fact that, as discussed above, P-AC margins are more difficult to interpret as measures of competition than P-MC margins.

Since time series are too short in Hong Kong SAR to allow the construction of capital stocks, P-AC margins will be measured without any allowance for capital costs. DHP (1986) noted that under the assumptions that labor is completely variable, capital is completely fixed, and short-run returns to scale are constant, a P-AC margin which excludes capital costs is equal to a P-MC margin. To the extent that these assumptions are violated, the P-AC margins measured in this paper will be imperfect measures of P-MC margins.

- Econometric estimation of P-MC margins. In this paper three methodologies for estimating P-MC margins were considered: Hall (1988), DHP (1988), and Roeger (1995). All of these methods assume a constant margin over time, constant returns and no fixed or adjustment costs. Only a modified version of the Roeger methodology is feasible for Hong Kong SAR, but this "modified Roeger" method yields results which are highly correlated with those from other methods.

\footnotetext{
${ }^{8}$ This paper discusses both markups (Price/Cost) and margins [(Price-Cost)/Price] depending on which is appropriate for the theory or estimation technique being discussed. The two concepts are obviously very closely related; higher markups always imply higher margins, and vice versa.

${ }^{9}$ Morrison (1990) estimates P-MC and P-AC markups while allowing for adjustment costs for capital and labor (which generate variance in capacity utilization), nonconstant returns, and time-varying markups. In estimating her structural model, Morrison makes use of both nominal and (separately deflated) real data on three purely marginal inputs: materials, energy, and purchased services, in addition to her data on the quasi-fixed labor and capital inputs. This data is essential to giving her estimation approach sufficient power, and given its absence in Hong Kong SAR, this methodology is not attempted.
} 
The Hall and DHP methodologies both use instrumental variables to identify changes in an industry's output which are not related to changes in its productivity. ${ }^{10}$ These exogenous changes in output are then used to infer marginal cost and P-MC margins. The respective Hall and DHP estimating equations are:

$$
\begin{aligned}
& d q-d k=\mu \cdot a \cdot(d l-d k)+d(\ln A) \\
& d T F P=\gamma \cdot(d q-d k)+(1-\gamma) \cdot d(\ln A)
\end{aligned}
$$

where dq, dk, dl, and dTFP are changes in the logs of output, capital, labor, and measured TFP, $a$ is the observed labor share, $\mu$ is the P-MC markup, and $\gamma$ is the P-MC margin. ${ }^{11}$ The change in unobserved true productivity $(\mathrm{d} \ln \mathrm{A})$ is treated as the error term in the estimation, and the identifying assumption is that the demand instrumental variables are uncorrelated with true productivity growth. Hall used defense spending, world oil prices, and the political party of the President as demand instruments for U.S. industries, but these instruments have been criticized as being only weakly correlated with output and inappropriate for other countries. Fortunately, DHP found that using aggregate GDP as a demand instrument yielded similar results, and this is the instrumenting approach followed in this study. ${ }^{12}$

The Roeger method, in contrast, eliminates the unobserved productivity term from the estimating equation, removing the need for instrumental variables. ${ }^{13}$ Instead of using the

\footnotetext{
${ }^{10}$ The need for instrumental variables can be most intuitively seen from considering the analogous problem of estimating marginal cost from data on cost and output. Output is endogenous to cost, in that an increase in productivity will both reduce cost and increase output. One therefore needs to use demand-shifting instrumental variables to identify the effect on cost of a demand-related increase in output.

${ }^{11}$ This equations are derived and discussed in more detail in Appendix I. For reference, the Hall, DHP, and Roeger estimating equations are A2, A3, and A6, respectively.

${ }^{12}$ The fact that using aggregate GDP and using the Hall instruments yields similar results suggests that either aggregate GDP is uncorrelated with true industry productivity (i.e., there are no economy-wide productivity shocks) or that the Hall instruments were so weak that his estimates are biased towards OLS (see Bound, Jaeger, and Baker, 1995).

${ }^{13}$ Roeger verified that exogeneity of his right-hand side variable held using U.S. data, and this result is confirmed in Hausman (1978) tests in Table 5. For the OECD dataset, however, Roeger's exogeneity assumption is not supported by the data-OLS estimates of P-MC margins are upwardly biased by about 0.1 . As a result, both OLS and IV estimates will be made in this paper.
} 
primal (output-based) Solow residual, Roeger takes the difference between the primal and dual (price-based) residuals, eliminating the productivity term. His estimating equation is:

$$
(d q+d p)-a \cdot(d l+d w)-(1-a) \cdot(d k+d r)=\gamma \cdot[(d q+d p)-(d k+d r)]
$$

Notice that the Roeger method requires only nominal data, which is very helpful given the lack of industry-level price deflators in Hong Kong SAR. It does require data on current price capital inputs, however. Since capital stocks are unavailable for Hong Kong SAR, a modified Roeger methodology using gross fixed capital formation as the capital input is estimated. ${ }^{14}$

\section{Data Availability and Sources}

Data is available for Hong Kong SAR for 85 industries (26 manufacturing and 59 service) that cover 5 out of 9 major sectors in the economy. ${ }^{15}$ As mentioned above, the available data has several important limitations, however. First, only 8 years (1990-97) and 12 years (1986-97) of data are available for manufacturing and service industries, respectively. ${ }^{16}$ This makes it impossible to construct industry-level capital stocks and harder to identify marginal costs and the cyclicality of markups. The latter is complicated by the fact that the particular 12 years for which we have data was one of the most stable periods in Hong Kong SAR history, especially the 8 years (1990-97) for which we have manufacturing data. Second, industry-level output and input price deflators are not available for Hong Kong SAR. These deflators are especially important for Hong Kong SAR given the dramatic changes in relative prices in during the

\footnotetext{
${ }^{14}$ One might worry that a fast growing economy like Hong Kong SAR would be off its balanced growth path and have a more rapidly increasing capital-output ratio than an average OECD economy and, therefore, a higher GFCF-capital stock ratio. If this were true, the modified Roeger methodology would produce downwardly biased estimates of the P-MC margin. Young (1995) reports 1986-91 output and capital stock growth of 6.3 percent and 6.2 percent a year, respectively, suggesting that this is not a major issue in the period studied.

${ }^{15} \mathrm{~A}$ list of the 85 industries included in the study is provided in Annex Table 1. The data cover manufacturing, construction, trade, transportation/storage/communication (TSC), and finance/insurance/real estate/business services (FIRE) and exclude agriculture, mining, utilities, and community, social, and personal services. Data is only available for only a portion of TSC (transportation) and FIRE (real estate). The portions of the five sectors covered accounted for 54.3 percent of GDP in 1997 (Table 8).

${ }^{16}$ Throughout the paper, services will be used to refer to all nonmanufacturing sectors in the sample, including construction. Although construction is usually considered part of industry, it fits more naturally with the service industries in Hong Kong SAR because it is a nontraded, growing sector.
} 
period studied, ${ }^{17}$ and their absence restricts us to using the Roeger methodology for estimating P-MC margins. ${ }^{18}$

The Hong Kong SAR data is matched with data for 14 countries $^{19}$ from the OECD ISDB and STAN databases. The OECD data is available for 27 manufacturing industries and 11 nonmanufacturing industries; 26 and 7 of which match with the Hong Kong SAR data. Due to the shortness of the manufacturing time series, the 26 matching manufacturing industries are pooled into the 14 manufacturing categories in the ISDB, which helps increase the power of estimates for Hong Kong SAR. Value-added data, and thus margins, are unavailable for communication and finance/insurance for Hong Kong SAR, and thus the combined Hong Kong SAR-OECD sample includes 14 manufacturing and 5 nonmanufacturing industries.

\section{HOW COMPETITIVE IS HONG KONG SAR?}

The three measures of margins presented in this section yield slightly inconsistent conclusions about how the competition of Hong Kong SAR's industries compares with the OECD or the United States (Figure 1):

- $\quad$ Price-average cost margins defined on value added are generally higher in Hong Kong SAR, especially in manufacturing (Table 1).

- $\quad$ P-AC margins defined on gross output are slightly higher on average in Hong Kong SAR in manufacturing, and slightly lower in services (Table 1$){ }^{20}$

\footnotetext{
${ }^{17}$ Dodsworth and Mihaljek (1997) estimated annual output price increases from 1983-94 of 2.1 percent for manufacturing, 5.2 percent for trade, 4.0 percent for transport, storage, and communication, 10.7 percent for FIRE, and 10.1 percent for community social and personal services.

${ }^{18}$ The Dodsworth-Mihaljek estimated output price deflators involve assumptions which are especially difficult for key industries such as real estate and wholesale-retail trade. In addition, there are no separate input price deflators. Assuming proportionate changes in input and output prices is problematic given the large changes in relative prices. As a result, their approach to estimating industry-level price deflators was not followed.

${ }^{19}$ Australia, Belgium, Canada, Denmark, Finland, France, (western) Germany, Italy, Japan, the Netherlands, Norway, Sweden, the United Kingdom, and the United States.

${ }^{20}$ Defining margins on gross output is more theoretically sound since firms mark up material costs as well as labor and capital costs, but since gross output of service industries is unavailable for the OECD countries, value-added P-AC margins are also calculated.
} 
$-11-$

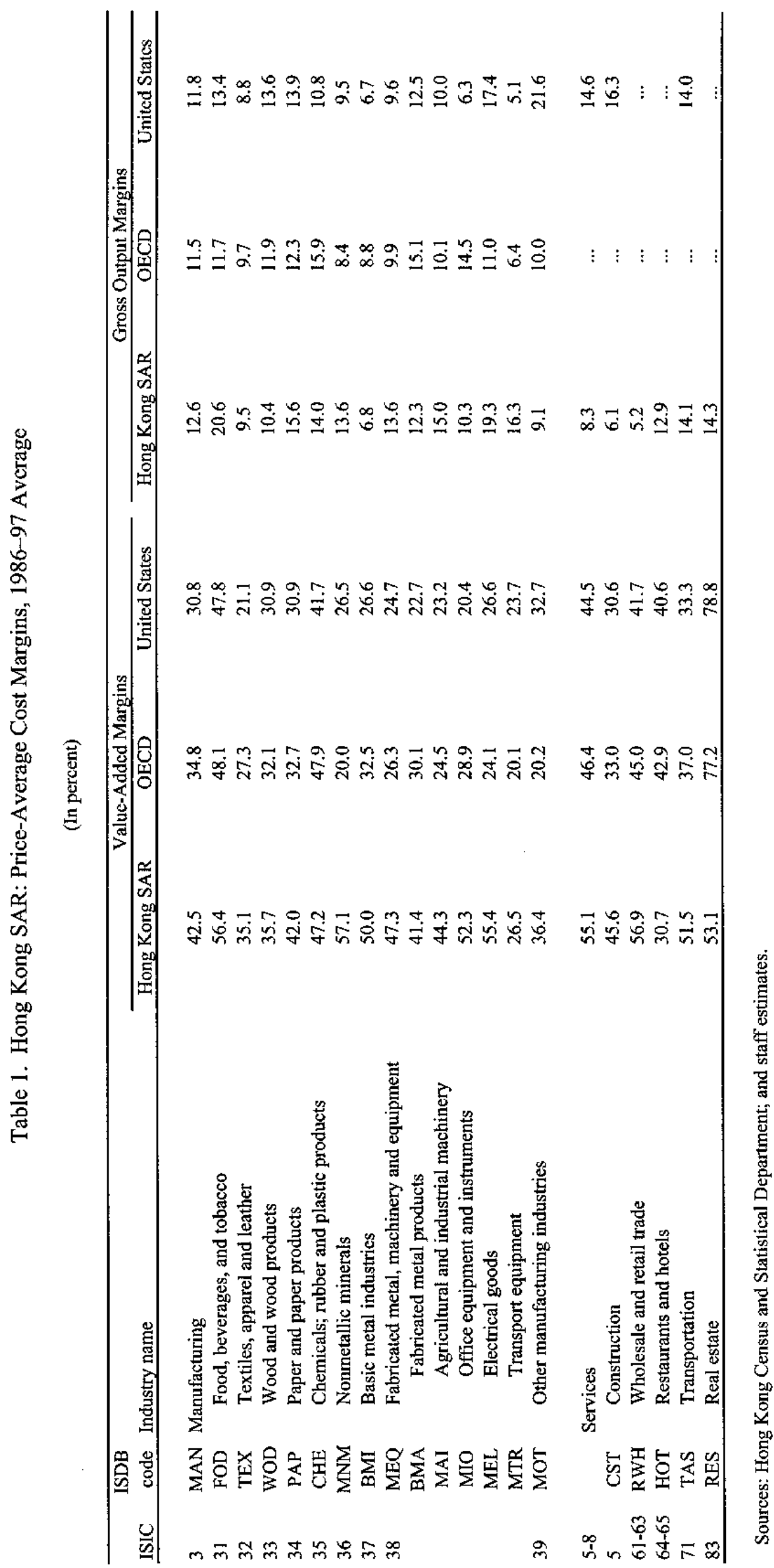



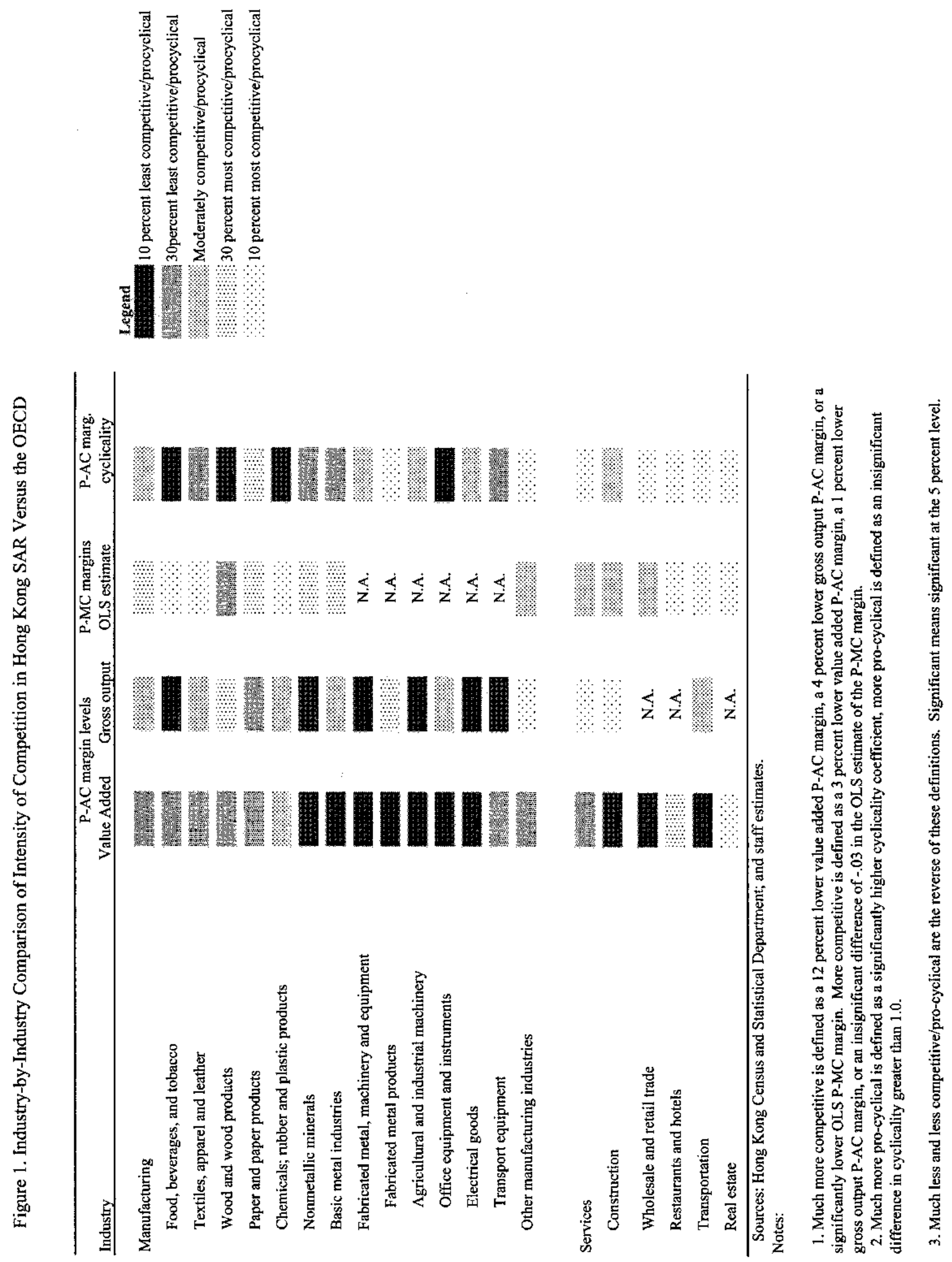
- $\quad$ P-MC margins, as estimated by the modified Roeger methodology, are lower in Hong Kong SAR in both manufacturing and services (Table 2).

Although comparing Hong Kong SAR with the OECD average yields different results depending on the measure, on almost all of measures, Hong Kong SAR is neither the most nor the least competitive of our 15 sample countries (Table 3). This suggests that Hong Kong $\mathrm{SAR}$ is neither significantly more nor significantly less competitive than OECD countries.

Of course, it may be the case that given its fixed exchange rate and extreme openness and exposure to external shocks, Hong Kong SAR needs to be significantly more competitive than the average OECD economy. Figure 2 compares the results in this section for Hong Kong SAR across industries to identify industries in which competition could potentially be stronger. These comparisons require stronger assumptions than comparisons across countries, as discussed in Section $\Pi$, but may nonetheless be informative. The plurality of the measures in Figure 2 suggest that food processing, nonmetallic minerals, real estate and transportation are less competitive than the average industry, while construction, restaurants and hotels, and textiles and apparel are among the most competitive. It should be noted, however, that the nonmetallic minerals industry comprises an extremely small portion of total manufacturing output.

\section{Potential Biases in the Competition Measures}

Both the P-AC and the estimated P-MC margins are imperfect estimates of true P-MC margins, as discussed in Section II. Recall that for P-AC margins that exclude capital costs to equal P-MC margins, capital would have to be completely fixed, labor completely variable, and returns to scale would have to be constant. Obviously these assumptions do not hold in reality, but the primary concern in this paper is whether making them distorts the comparison between Hong Kong SAR and the OECD. For example, even if capital and labor were both only partly fixed, if they were fixed to the same degree and if factor shares were similar in Hong Kong SAR and the OECD, the Hong Kong SAR-OECD difference in P-AC margins should still be an unbiased indicator of differences in P-MC margins.

On the other hand, if Hong Kong SAR uses technologies or has a product mix that involved less fixed costs across all factors (and thus higher MC/AC ratios), it could have simultaneously higher P-AC margins and lower P-MC margins. Furthermore, if Hong Kong SAR has a higher capital share in value-added or output, this could upwardly bias its measured 
Table 2. Hong Kong SAR: OLS and IV Estimates of P-MC Markups Using the Modified Roeger Methodology

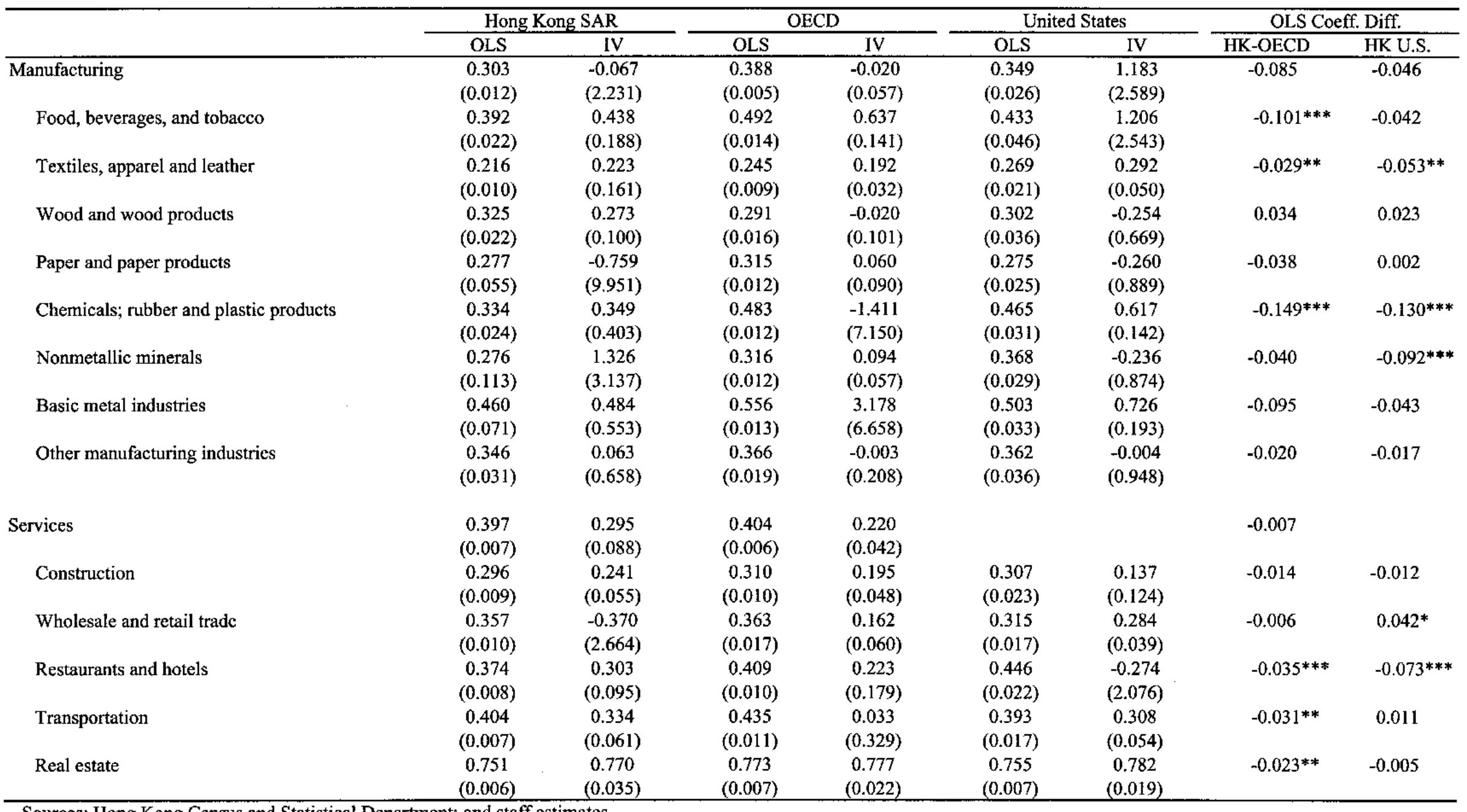

Sources: Hong Kong Census and Statistical Department; and staff estimates.

Notes:

1. Regressions are pooled for industries containing more than one component industry.

2. Significance at the 10,5 , and 1 percent level is indicated by one, two, and three asterisks, respectively. 
Table 3. Hong Kong SAR's Relative Rank on Different Measures of Competitiveness

\begin{tabular}{lllcc}
\hline Measure & Margin & Definition & Manufacturing & Services \\
\hline Level & P-AC & Value added & 14 & 13 \\
Level & P-AC & Gross output & 10 & N.A. \\
Level & P-MC & Value added & 1 & 9 \\
Cyclicality & P-AC & Value added & 13 & 3 \\
Cyclicality & P-AC & Gross output & 9 & 2 \\
\hline
\end{tabular}

Sources: Hong Kong Census and Statistical Department; and staff estimates.

Notes:

1. A lower rank number implies more competition or more pro-cyclical margins.

2. Rankings are out of the 15 sample countries, except for P-MC margins, where they are out of 13 . 
Figure 2. Comparison of Intensity of Competition Across Industries in Hong Kong SAR

\begin{tabular}{lcccc}
\hline Industry & \multicolumn{2}{c}{ P-AC Margin Levels } & P-MC Margins & P-AC Margins \\
Cyclicality
\end{tabular}

Legend 2. Thentitive/procyclical :.1:.:.:. Moderately competitive/procyclical

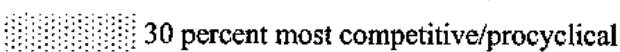

a 10 percent most competitive/procyclical

Sources: Hong Kong Census and Statistical Department; and staff estimates. 
P-AC margin differentially. ${ }^{21}$ Given the limited data available for Hong Kong SAR, there is little one can do but accept that the P-AC margins may be slightly biased; this is part of why this paper contains multiple measures.

The P-MC margins estimated by the "modified Roeger" methodology are likewise imperfect measures. The IV results for Hong Kong SAR are fairly erratic with high standard errors, thus we rely mainly on the OLS results (Table 2). Comparing the modified Roeger method with the DHP and unmodified Roeger methods for U.S. and OECD data suggest that the OLS modified Roeger estimates may be downwardly biased (Table 4). This would be the case if growth in gross fixed capital formation was either an especially noisy proxy for growth in current price capital input. ${ }^{22}$ As with P-AC margins, we are especially concerned with sources of differential bias. The period studied was actually a fairly stable one for Hong Kong SAR; from 1986-97 the standard deviation of the growth rate in aggregate GFCF was 4.3 percent in both Hong Kong SAR and the United States, suggesting that any bias due to measurement error should be comparable across at least these two countries. For OECD countries, the OLS version of the modified Roeger method yields results that are highly correlated with other methods across both countries and industries, so the slightly lower P-MC margins estimated for Hong Kong SAR by the modified Roeger methodology suggest that other methodologies would also have produced slightly lower estimates (Table 5).

\section{Evolution OF COMPETITION IN THE HONG KONG SAR ECONOMY}

This section examines both whether margins have increased or decreased within industries and whether the rapid sectoral shift which has occurred in Hong Kong SAR has shifted the economy into less competitive industries. As with margin levels, the different measures are inconsistent. The balance of evidence, however, suggests that Hong Kong SAR has become slightly less competitive in the last 10 years:

\footnotetext{
${ }^{21}$ Developing countries often have higher capital shares (which the value-added P-AC margin as defined in this paper is equivalent to) than developed countries. Two possible explanations of this phenomenon are higher markups or less than unit elasticities of capital-labor substitution.

${ }^{22}$ The bias from GFCF growth being systematically larger or smaller than capital input growth than capital input growth is coincidentally actually quite small, since capital input growth is weighted by the capital share in the numerator and the mean capital share ( 40 percent) is actually very close to the mean estimator of the P-MC.
} 
Table 4. Hong Kong SAR: Four Methodologies for Measuring P-MC Margins

\begin{tabular}{|c|c|c|c|c|c|c|c|c|c|c|c|c|c|c|c|}
\hline \multirow[b]{2}{*}{ Sector } & \multirow[b]{2}{*}{ Dataset } & \multirow[b]{2}{*}{ Output measure } & \multirow[b]{2}{*}{ Labor measure } & \multicolumn{3}{|c|}{ Hall } & \multicolumn{3}{|c|}{ DHP } & \multicolumn{3}{|c|}{ Roeger } & \multicolumn{3}{|c|}{ Modified Roeger } \\
\hline & & & & OLS & IV & Diff & OLS & IV & Diff & OLS & IV & Diff & OLS & IV & Diff \\
\hline \multirow[t]{2}{*}{ Manufacturing } & United States & Gross output & Hours & 0.264 & 0.341 & 0.077 & 0.387 & 0.346 & $-0.04 !$ & 0.324 & 0.321 & -0.003 & 0.285 & 0.270 & -0.015 \\
\hline & & & & $(0.013)$ & $(0.019)$ & 0.000 & $(0.011)$ & $(0.019)$ & 0.008 & $(0.008)$ & $(0.014)$ & 0.777 & $(0.006)$ & $(0.020)$ & 0.441 \\
\hline \multirow[t]{2}{*}{ Manufacturing } & United States & Value added & Hours & 0.608 & 0.649 & 0.041 & 0.879 & 0.706 & -0.173 & 0.729 & 0.757 & 0.028 & 0.662 & 0.520 & -0.141 \\
\hline & & & & $(0.023)$ & $(0.034)$ & 0.187 & $(0.007)$ & $(0.026)$ & 0.000 & $(0.017)$ & $(0.039)$ & 0.425 & $(0.012)$ & $(0.042)$ & 0.000 \\
\hline \multirow[t]{2}{*}{ Manufacturing } & United States & Valuc added & Employment & 0.652 & 0.708 & 0.056 & 0.900 & 0.770 & -0.130 & 0.729 & 0.757 & 0.028 & 0.662 & 0.520 & -0.141 \\
\hline & & & & $(0.022)$ & $(0.029)$ & 0.060 & $(0.006)$ & $(0.021)$ & 0.000 & $(0.017)$ & $(0.039)$ & 0.425 & $(0.012)$ & $(0.042)$ & 0.000 \\
\hline \multirow[t]{2}{*}{ Manufacturing } & OECD & Value added & Employment & -0.082 & 0.721 & 0.803 & 0.827 & 0.721 & -0.106 & 0.728 & 0.628 & -0.100 & 0.388 & -0.020 & -0.409 \\
\hline & & & & $(0.049)$ & $(0.016)$ & 0.000 & $(0.008)$ & $(0.016)$ & 0.000 & $(0.011)$ & $(0.024)$ & 0.000 & $(0.005)$ & $(0.057)$ & 0.000 \\
\hline \multirow[t]{2}{*}{ Manufacturing } & Hong Kong SAR & Value added & Employment & & & & & & & & & & 0.303 & -0.067 & -0.370 \\
\hline & & & & & & & & & & & & & $(0.012)$ & (2.231) & 0.868 \\
\hline \multirow[t]{2}{*}{ Services } & OECD & Value added & Employment & 0.108 & 0.717 & 0.608 & 0.713 & 0.717 & 0.003 & 0.632 & 0.546 & -0.086 & 0.404 & 0.220 & -0.184 \\
\hline & & & & $(0.040)$ & $(0.028)$ & 0.000 & $(0.013)$ & $(0.028)$ & 0.897 & $(0.017)$ & $(0.052)$ & 0.078 & $(0.006)$ & $(0.042)$ & 0.000 \\
\hline \multirow[t]{2}{*}{ Services } & Hong Kong SAR & Value added & Employment & & & & & & & & & & 0.397 & 0.295 & -0.102 \\
\hline & & & & & & & & & & & & & $(0.007)$ & $(0.088)$ & 0.243 \\
\hline \multirow[t]{2}{*}{ Total economy } & OECD & Value added & Employment & -0.039 & 0.721 & 0.759 & 0.810 & 0.721 & -0.089 & 0.713 & 0.617 & -0.095 & 0.391 & 0.033 & -0.358 \\
\hline & & & & $(0.036)$ & $(0.014)$ & 0.000 & $(0.007)$ & $(0.014)$ & 0.000 & $(0.005)$ & $(0.021)$ & 0.000 & $(0.004)$ & $(0.042)$ & 0.000 \\
\hline \multirow[t]{2}{*}{ Total economy } & Hong Kong SAR & Value added & Employment & & & & & & & & & & 0.376 & 0.304 & -0.071 \\
\hline & & & & & & & & & & & & & $(0.006)$ & $(0,087)$ & 0.409 \\
\hline
\end{tabular}

Sources: Hong Kong Census and Statistical Department; and staff estimates.

Notes:

1. The number below the OLS-IV difference in italics is the p-value of a Hausman (1978) test.

2. The U.S. dataset used in these tests is the Bartlesman-Becker-Gray (1996) dataset collapsed down to the 2-digit SIC level, which should be very similar to the data used by Hall (1988)

and Roeger (1995). 
Table 5. Hong Kong SAR: Correlation of P-MC Margin Estimates Using Different Methodologies

\begin{tabular}{|c|c|c|c|c|c|c|c|c|c|}
\hline \multicolumn{2}{|c|}{ Industry Results } & $\begin{array}{l}\text { OLS } \\
\text { Hall } \\
\end{array}$ & \multirow{2}{*}{$\begin{array}{l}\text { OLS } \\
\text { DHP } \\
\end{array}$} & \multirow{2}{*}{$\begin{array}{c}\text { OLS } \\
\text { Roeger }\end{array}$} & \multirow{2}{*}{$\begin{array}{c}\text { OLS } \\
\text { Mod. Roeg. }\end{array}$} & \multirow{2}{*}{$\begin{array}{c}\text { IV } \\
\text { Hall } \\
\end{array}$} & \multirow{2}{*}{$\begin{array}{c}\text { IV } \\
\text { DHP }\end{array}$} & \multirow{2}{*}{$\begin{array}{c}\text { IV } \\
\text { Roeger }\end{array}$} & \multirow{2}{*}{$\begin{array}{c}\text { IV } \\
\text { Mod. Roeg. }\end{array}$} \\
\hline OLS & Hall & 1 & & & & & & & \\
\hline OLS & DHP & 0.02 & 1 & & & & & & \\
\hline OLS & Roeger & 0.08 & 0.88 & 1 & & & & & \\
\hline OLS & Mod. Roeger & 0.10 & 0.68 & 0.84 & 1 & & & & \\
\hline IV & Hall & 0.48 & -0.06 & -0.07 & -0.19 & 1 & & & \\
\hline IV & DHP & 0.20 & 0.92 & 0.87 & 0.69 & -0.01 & 1 & & \\
\hline IV & Roeger & 0.02 & 0.53 & 0.50 & 0.56 & -0.17 & 0.41 & 1 & \\
\hline IV & Mod. Roeger & 0.31 & -0.03 & 0.04 & 0.03 & 0.48 & -0.07 & 0.17 & 1 \\
\hline \multirow{2}{*}{\multicolumn{2}{|c|}{ Country Results }} & OLS & OLS & OLS & OLS & IV & IV & IV & IV \\
\hline & & Hall & DHP & Roeger & Mod. Roeg. & Hall & DHP & Roeger & Mod. Roeg. \\
\hline OLS & Hall & 1 & & & & & & & \\
\hline OLS & DHP & -0.18 & 1 & & & & & & \\
\hline OLS & Roeger & -0.55 & 0.34 & 1 & & & & & \\
\hline OLS & Mod. Roeger & -0.12 & 0.38 & 0.67 & 1 & & & & \\
\hline IV & Hall & 0.31 & 0.56 & -0.10 & 0.04 & 1 & & & \\
\hline IV & DHP & 0.13 & 0.60 & -0.24 & 0.45 & 0.51 & 1 & & \\
\hline IV & Roeger & -0.63 & -0.09 & 0.66 & 0.68 & -0.40 & -0.76 & 1 & \\
\hline IV & Mod. Roeger & 0.20 & 0.51 & 0.56 & 0.41 & 0.15 & 0.31 & -0.14 & 1 \\
\hline
\end{tabular}

Sources: Hong Kong Census and Statistical Department; and staff estimates.

Notes:

1. Bold italics indicate correlation coefficients highlighted in the text.

2. Although the Hall methodology estimates $\mathrm{P} / \mathrm{MC}$ and the others estimate $(\mathrm{P}-\mathrm{MC}) / \mathrm{P}$, the correlation should still be high for the relevant range of values. 
- Value-added P-AC margins have declined in services, but they have risen in manufacturing and gross output P-AC margins have risen in both sectors (Table 6). ${ }^{23}$

- $\quad$ P-MC margins, as estimated by the modified Roeger methodology, have been stable in services and declining slightly in manufacturing, although this decline is not statistically significant. $^{24}$

- The shift in the economy towards services has raised average P-MC margins while having a minimal effect on average P-AC margins (Table 7). ${ }^{25}$

The magnitudes of some of the changes in margins are quite large relative to the Hong Kong SAR-OECD level differences discussed in the previous section. Table 6 suggests that valueadded margins have increased by 7.1 percentage points over 10 years in manufacturing and decreased by 6.0 percentage points in services, while gross output margins have increased by 1.9 and 1.4 percentage points, respectively. Table 7 shows that the shift in industry mix toward services should have increased the economy-average P-MC margin by 7.7 percentage points. ${ }^{26}$ In contrast, the Hong Kong SAR-OECD level differences in value-added P-AC, gross output $\mathrm{P}-\mathrm{AC}$, and $\mathrm{P}-\mathrm{MC}$ margins were approximately 10,1 , and 2 percentage points, respectively. Given the inconsistency of the measures and their potential biases (discussed in Section III), one should be cautious in drawing firm conclusions above the change in the level of competition in Hong Kong SAR.

${ }^{23}$ Figure 3 shows the evolution of these margins over time. The downward trend in servicesector value added margins and upward trend in the other margins can be observed, along with the pro-cyclicality of service sector value-added margins and counter-cyclicality of manufacturing sector margins.

${ }^{24}$ The trend in P-MC margins is estimated by including an interaction term in the modified Roeger regression. The estimated coefficient implies an annual decline of 0.6 and 0.04 percentage points in the P-MC margin for manufacturing and nonmanufacturing, respectively. Neither estimate is significant, however.

${ }^{25}$ See Annex Table 2 for the evolution of the industrial structure of the economy.

${ }^{26}$ Estimating the effect of the shift in industry mix involves treating P-MC margins as comparable across industries. As noted in Section II, inferring differences in competition or collusion from differences in P-MC margins involves assuming that demand elasticities are the same, which is arguably less likely to be true across industries than within an industry across countries. 
Table 6. Hong Kong SAR: Trend in Price-Average Cost Margins

(Percentage change per year)

\begin{tabular}{|c|c|c|c|c|}
\hline \multirow[b]{2}{*}{ Industry } & \multicolumn{2}{|c|}{ Cyclically Adjusted } & \multicolumn{2}{|c|}{ Unadjusted } \\
\hline & Value added & Gross output & Value added & Gross output \\
\hline Manufacturing & $0.7^{* * *}$ & 0.2 & $0.4^{* *}$ & $0.2^{* *}$ \\
\hline Food, beverages, and tobacco & 0.3 & $0.5^{* * *}$ & $-1.2 * * *$ & $-0.3^{*}$ \\
\hline Textiles, apparel and leather & $1.9 * *$ & 0.3 & $0.9^{* *}$ & 0.1 \\
\hline Wood and wood products & $1.6 * * *$ & $0.5^{* * *}$ & $0.6^{* *}$ & 0.1 \\
\hline Paper and paper products & $-4.1 * * *$ & $-1.8 * *$ & $-2.4 * * *$ & $-0.9 * * *$ \\
\hline Chemicals; rubber and plastic products & 1.0 & 0.2 & 0.1 & -0.1 \\
\hline Nonmetallic minerals & $5.3^{* *}$ & $2.5 * * *$ & $2.7^{* * *}$ & $1.5 * * *$ \\
\hline Basic metal industries & 1.7 & 0.4 & -0.5 & -0.2 \\
\hline Fabricated metal, machinery and equipment & 0.6 & 0.3 & $0.4^{* *}$ & $0.4 * * *$ \\
\hline Fabricated metal products & $-2.5^{* * *}$ & $-1.2 * * *$ & $-1.2^{* * *}$ & $-0.5^{* *}$ \\
\hline Agricultural and industrial machinery & -0.9 & $-0.6^{*}$ & $-0.6^{*}$ & -0.1 \\
\hline Office equipment and instruments & $1.6^{* *}$ & $0.7^{* *}$ & 0.1 & 0.2 \\
\hline Electrical goods & 2.4 & 0.8 & $3.1 * * *$ & $1.6 * * *$ \\
\hline Transport equipment & -1.0 & -0.5 & $-0.5^{*}$ & -0.3 \\
\hline Other manufacturing industries & -1.2 & -0.6 & 0.5 & 0.0 \\
\hline Services & $-0.6^{* * *}$ & $0.1 * * *$ & $-0.6^{* * *}$ & $0.1 * * *$ \\
\hline Construction & 0.1 & 0.1 & 0.4 & 0.0 \\
\hline Wholesale and retail trade & $-0.6^{* * *}$ & 0.0 & $-0.6 * * *$ & 0.0 \\
\hline Restaurants and hotels & $-0.8 * * *$ & $-0.3 * * *$ & $-0.8 * * *$ & $-0.3 * *$ \\
\hline Transportation & $-0.9 * * *$ & -0.1 & $-0.9^{* * *}$ & -0.1 \\
\hline Real estate & $-3.5^{* * * *}$ & $-2.9 * * *$ & -1.1 & -0.6 \\
\hline
\end{tabular}

Sources: Hong Kong Census and Statistical Department; and staff estimates.

Notes:

1. One, two, and three asterisks represent significance at the 10 percent, 5 percent, and 1 percent level, respectively.

2. Numbers reported are coefficients on the time trend in a regression of the P-AC margin on a time trend and the GDP gap

(for the cyclically adjusted measure).

3. The GDP gap is constructed by applying a Hodrik-Prescott filter (lamba $=1600)$ to quarterly data and then aggregating the quarterly gap into annual data. 
Table 7. Hong Kong SAR: Effect of Industry Mix Shift on Margin Levels and Cyclicality

(In percent)

\begin{tabular}{lcccc}
\hline & \multicolumn{2}{c}{ P-AC margins } & P-MC margin & P-AC Cyclicality \\
\cline { 2 - 3 } & Value Added & Gross Output & & \\
At 1986 industry mix & & & 33.3 & 0.63 \\
At 1997 industry but 1986 real estate share & 48.1 & 10.2 & 38.3 & 1.19 \\
At 1997 industry mix & 50.7 & 9.2 & 41.0 & 1.51 \\
& 50.8 & 9.6 & +0.6 & +7.7 \\
Total industry mix shift effect & & & +2.7 & +0.87 \\
Effect of increase in real estate share & +2.8 & +0.4 & +0.32 \\
\end{tabular}

Sources: Hong Kong Census and Statistical Department; and staff estimates.

Note: Higher numbers imply less competition, except for P-AC margin cyclicality. 


\section{CyClicality OF MARKuPS ANd ADJUSTMENT IN HONG KONG SAR}

One of the objectives of this chapter was to understand whether imperfect competition has adversely affected cyclical adjustment in Hong Kong SAR. If imperfect competition generates countercyclical markups, as predicted by the Rotemburg-Saloner (1986) model, a worsening of competition could slow down price adjustment, creating problems for an open economy with a fixed exchange rate.

\section{An Illustration of How Cyclicality in Markups Affects Adjustment}

To see how imperfect competition can affect the adjustment process, consider a simple model of aggregate supply and demand. Expenditure, and thus aggregate demand, is determined by a simple quantity theory of money:

$$
P Y=V M
$$

Where $\mathrm{Y}$ refers to aggregate output, $\mathrm{V}$ is the velocity of money, and $\mathrm{M}$ is the stock of money supply. Prices are set by firms which mark up their marginal wage (W) and material costs (MAT) depending on the degree of competition in their markets:

$$
P=c(M A T, W) \cdot M U
$$

The aggregate supply relationship governs how sticky price adjustment in response to deviations of aggregate output from its long-run trend is:

$$
d p(y)=s_{w} \cdot d w(y)+s_{m} \cdot d m a t(y)+d m u(y)
$$

where lower case letters indicate logarithms, $y$ is the deviation of output from its long-run level and $s_{\mathrm{w}}$ and $\mathrm{s}_{\mathrm{m}}$ are the share of wages and materials in cost. Ceteris paribus, if markups are more countercyclical, prices will fall less rapidly during recessions and rise less rapidly during booms.

Consider the effects of an adverse monetary shock to aggregate demand. Prices are initially sticky, so the immediate effect of the monetary shock is an equally sized decline in both nominal and real output. A below trend real output level, however, leads to a decline in prices and thus a recovery of real output which continues until output reaches its long-run level and the effect of the monetary shock is fully reflected in prices. If markups are countercyclical, price adjustment is slower and the recession lasts longer.

Recessions resulting from a supply shock are also more severe when markups are countercyclical. Consider the effects of a permanent increase in oil price inflation. If monetary policy is unchanged, the increased oil price inflation will lead over time to a higher price level and lower real output level. This process continues until real output has fallen enough so that changes in wages and markups are reduced enough to restore price stability (or, alternatively, 
until inflation returns to equal the rate of money creation). Absent a change in monetary policy or a reduction in oil price inflation, real output is permanently lower. The size of the decline in real output is greater when markups are counter-cyclical, since more real output decline is required to offset the higher oil price inflation.

\section{How Cyclical Are Markups in Hong Kong SAR?}

This section measures the cyclicality of P-AC margins in Hong Kong SAR compared with OECD countries and tests whether the structural shift towards services has made P-AC markups more counter-cyclical. As discussed in Section II, the relative cyclicality of P-MC margins can be inferred from the cyclicality of $\mathrm{P}-\mathrm{AC}$ margins if we assume that capacity utilization responds identically to industry output in all countries. ${ }^{27}$ Contrary to expectations, it was found that:

- $\quad$ P-AC margins are significantly more pro-cyclical in Hong Kong SAR than in the OECD in services, while they are slightly more counter-cyclical in manufacturing (Table 8).

- $\quad$ P-AC margins are more pro-cyclical in services. The shift in the economy to service therefore should have made aggregate P-AC margins more pro-cyclical (Table 7).

Therefore there is little evidence that increased counter-cyclicality of margins is slowing price adjustment in Hong Kong SAR. If one concludes that price adjustment has slowed, one may have to look elsewhere (e.g., factor markets) for the explanation.

Can we infer anything about competition from the cyclicality of margins? A majority of studies (at least as summarized in Rotemburg and Woodford, 1999) suggest that imperfect competition has created counter-cyclical P-MC margins, at least in the United States. If it is also true that more collusion means more counter-cyclical markups, which is what the Rotemburg-Saloner (1986) model predicts at all but very high levels of collusion, then the cyclicality of P-AC margins in Hong Kong SAR imply that services are more competitive and manufacturing is less competitive. To feel comfortable with this conclusion, however, one would have to eliminate all other sources of differences in cyclicality, such as differences in technology or the cyclical behavior of demand elasticity, which is difficult to do given the data available.

\footnotetext{
${ }^{27}$ If Hong Kong SAR uses lower fixed cost production techniques, then capacity utilization (as defined in Section $\Pi$ as the ratio of long-run minimum cost to produce the current quantity and current total cost) should be less pro-cyclical in Hong Kong SAR. Thus comparable cyclicality of P-MC margins would imply less pro-cyclical P-AC margins in Hong Kong SAR. Thus a technology-related bias should not explain the pro-cyclical P-AC margins in services in Hong Kong SAR.
} 
Table 8. Hong Kong SAR: Cyclicality of Price-Average Cost Margins

(Percentage point effect on the margin of a one percentage point change in the output gap)

\begin{tabular}{|c|c|c|c|c|c|c|}
\hline \multirow[b]{2}{*}{ Industry } & \multicolumn{3}{|c|}{ Value-Added Margins } & \multicolumn{3}{|c|}{ Gross Output Margins } \\
\hline & Hong Kong SAR & OECD & Diff & Hong Kong SAR & OECD & Diff \\
\hline Manufacturing & -0.43 & 0.32 & -0.75 & 0.16 & 0.03 & 0.12 \\
\hline Food, beverages, and tobacco & -3.45 & -0.78 & $-2.67^{* *}$ & -1.91 & -0.12 & $-1.78^{* * * *}$ \\
\hline Textiles, apparel and leather & -2.21 & -0.24 & -1.97 & -0.55 & -0.05 & -0.50 \\
\hline Wood and wood products & -2.47 & 0.03 & $-2.50^{* * *}$ & -0.97 & 0.03 & $-1.00 * * *$ \\
\hline Paper and paper products & 3.92 & 0.30 & 3.63 & 2.05 & 0.20 & 1.85 \\
\hline Chemicals; rubber and plastic products & -2.14 & 0.15 & $-2.294 * *$ & -0.76 & 0.02 & -0.78 \\
\hline Nonmetallic minerals & -6.03 & -4.71 & -1.32 & -2.37 & -0.82 & -1.55 \\
\hline Basic metal industries & -5.00 & 0.72 & -5.72 & -1.40 & 0.23 & -1.63 \\
\hline Fabricated metal, machinery and equipment & -0.48 & -0.04 & -0.43 & 0.35 & 0.01 & 0.34 \\
\hline Fabricated metal products & 3.00 & 0.15 & $2.85 * *$ & 1.65 & 0.13 & $1.52 *$ \\
\hline Agricultural and industrial machinery & 0.82 & 0.28 & 0.54 & 1.22 & 0.12 & 1.10 \\
\hline Office equipment and instruments & -3.48 & 0.90 & $-4.38 * * *$ & -1.09 & 0.25 & $-1.34 * *$ \\
\hline Electrical goods & 1.55 & 0.61 & 0.94 & 1.80 & 0.24 & 1.56 \\
\hline Transport equipment & 1.08 & -0.09 & 1.17 & 0.57 & -0.08 & 0.65 \\
\hline Other manufacturing industries & 3.85 & 0.56 & $3.29 * *$ & 1.51 & 0.02 & 1.49 \\
\hline Services & 0.78 & 0.09 & $0.68 * * *$ & & & \\
\hline Construction & 0.60 & -0.08 & 0.68 & & & \\
\hline Wholesale and retail trade & 0.58 & -0.39 & $0.98 * * *$ & & & \\
\hline Restaurants and hotels & 1.34 & -0.10 & $1.45^{* * *}$ & & & \\
\hline Transportation & 1.01 & 0.06 & $0.95^{* * *}$ & & & \\
\hline Real estate & 5.52 & -0.30 & $5.82 * * *$ & & & \\
\hline
\end{tabular}

Sources: Hong Kong Census and Statistical Department; and staff estimates.

Notes:

1. One, two, and three asterisks represent significance at the $10 \%, 5 \%$, and $1 \%$ level, respectively.

2. Numbers reported are coefficients on the GDP gap in a regression of the P-AC margin on the GDP gap and a time trend. Regressions are for the OECD countries and for Hong Kong SAR industries containing more than one component industry.

3. The GDP gap is constructed by applying a Hodrik-Prescott filter (lamba $=1600$ ) to quarterly data and then aggregating the quarterly gap into annual data. 


\section{IMPLICATIONS FOR THE MEASUREMENT OF TFP GROWTH}

As Hall (1990) and Solow (1957) have observed, the traditional Solow-residual measure of TFP using observed factor shares is valid only under perfect competition. Under imperfect competition, the observed labor share will be below the coefficient in the Cobb-Douglas production function. If labor is 100 percent variable, the observed labor share will be:

$$
a=W L / P Q=\alpha / M U
$$

where $a$ is the observed labor share, $\alpha$ is the production function coefficient, and MU $=\mathrm{P} / \mathrm{MC}$. Assuming constant returns to scale, measured two-factor TFP is equal to:

$$
\ln T F P=a \cdot(M U-1) \cdot(\ln l-\ln k)+\ln A
$$

where TFP is the Solow residual and $A$ is true productivity. ${ }^{28}$ The source of the difference between measured and true productivity is the difference between the observed and true labor share when there is market power. Underestimating the labor share creates a downward bias in measured TFP growth in economies with rising capital-labor ratios, such as the Asian NIEs. ${ }^{29}$ Table 9 shows the magnitude of this bias for both OECD countries and the Asian NIEs assuming a average markup in every country of 1.5 , one of the lower estimates from

\footnotetext{
${ }^{28}$ The equation is the levels version of equation A1 in Appendix I. This is derived by substituting the observed labor share into the expression for the Solow residual. See Appendix I for details.

${ }^{29}$ There is a rapidly growing literature on biases to TFP measurement, most of which involve factor share mismeasurement. Nelson and Pack (1995), Rodrik (1997), Hsieh (1997), and Young (1998) have discussed the implications of low elasticities of factor substitution for measured factor shares and TFP growth. Barro (1998) points out that if social returns to capital exceed private returns, then observed capital shares could be underestimates of capital's contribution to growth. Sarel (1997) has reestimated TFP growth for Southeast Asian countries assuming the same sectoral factor shares prevail in all countries.
} 
Table 9. Hong Kong SAR: Bias to Measured TFP Implied by the Estimated Markups

(Average annual growth rates)

\begin{tabular}{|c|c|c|c|c|c|c|c|c|}
\hline & $\begin{array}{c}\text { Hong Kong } \\
\text { SAR } \\
1966-91 \\
\end{array}$ & $\begin{array}{c}\text { Singapore } \\
1966-90 \\
\end{array}$ & $\begin{array}{c}\text { Korea } \\
1966-90 \\
\end{array}$ & $\begin{array}{c}\text { Taiwan } \\
\text { Province } \\
\text { of China } \\
1966-90\end{array}$ & $\begin{array}{c}\text { United States } \\
1965-98\end{array}$ & $\begin{array}{c}\text { Japan } \\
1965-98 \\
\end{array}$ & $\begin{array}{c}\text { Germany } \\
1965-98\end{array}$ & $\begin{array}{c}\text { France } \\
1965-98\end{array}$ \\
\hline Output growth & 7.3 & 8.5 & 10.4 & 9.6 & 1.3 & 2.0 & 1.3 & 1.3 \\
\hline Capital input growth & 8.0 & 11.5 & 13.7 & 12.3 & 1.4 & 3.1 & 1.6 & 1.5 \\
\hline Labor input growth & 3.2 & 5.7 & 6.4 & 5.1 & 0.8 & 0.4 & 0.3 & 0.2 \\
\hline Labor share & $63 \%$ & $47 \%$ & $68 \%$ & $71 \%$ & $67 \%$ & $66 \%$ & $65 \%$ & $63 \%$ \\
\hline Adjusted labor share (labor $100 \%$ variable) & $94 \%$ & $71 \%$ & $102 \%$ & $107 \%$ & $100 \%$ & $99 \%$ & $97 \%$ & $94 \%$ \\
\hline Adjusted labor share (labor $80 \%$ variable) & $75 \%$ & $56 \%$ & $82 \%$ & $85 \%$ & $80 \%$ & $79 \%$ & $78 \%$ & $75 \%$ \\
\hline Bias to TFP growth (labor $100 \%$ variable) & -1.5 & -1.4 & -2.5 & -2.6 & -0.2 & -0.9 & -0.4 & -0.4 \\
\hline Bias to TFP growth (labor $80 \%$ variable) & -0.6 & -0.5 & -1.0 & -1.0 & -0.1 & -0.3 & -0.2 & -0.2 \\
\hline Measured TFP & 2.3 & -0.3 & 1.6 & 1.9 & 0.3 & 1.7 & 0.3 & 0.4 \\
\hline Actual productivity growth (labor $100 \%$ variable) & 3.8 & 1.1 & 4.1 & 4.5 & 0.5 & 2.6 & 0.7 & 0.8 \\
\hline Actual productivity growth (labor $80 \%$ variable) & 2.9 & 0.2 & 2.6 & 2.9 & 0.3 & 2.0 & 0.4 & 0.5 \\
\hline
\end{tabular}

Sources: Hong Kong Census and Statistical Department; and staff estimates.

Notes:

1. Data for the Asian NICs are from Young (1995), data for the G4 are from the OECD Economic Outlook. Labor and capital inputs are Young's adjusted inputs for the NICs and total employment and business-sector capital stock for the G4.

2. Bias is calculated assuming an economy-wide markup of 1.5 in every country. 
this paper. ${ }^{30}$ Estimates are shown for both the case where labor is 100 percent variable and where it is 80 percent variable. $^{31}$

Assuming labor is 100 percent variable, correcting for the imperfect competition bias raises measured TFP growth by about 0.3 percent a year for the United States, Germany, and France and 1.5 percent to 2.5 percent a year for the Asian NIEs. The adjusted labor shares are clearly too high to be realistic, however. Assuming that labor is 80 percent variable lowers the TFP adjustment to 0.5 percent to 1.0 percent for the NIEs and 0.1 percent to 0.2 percent for the advanced economies and produces at least plausible labor shares. The main conclusion to be drawn from this analysis is that comparisons of TFP growth between rapidly industrializing and advanced economies are sensitive to the factor shares used, the correct measurement of which is in turn sensitive to assumptions about imperfect competition and factor fixity. ${ }^{32}$ These issues are not as likely to affect comparisons between rapidly industrializing countries whose capital-labor ratios are changing at roughly the same rate. From 1966 -90, Hong Kong SAR achieved growth which was 1.2 percent p.a. slower than in Singapore despite capital and labor input growth that were 3.5 percent and 2.5 percent slower, respectively. ${ }^{33}$ No matter how you calculate it, Hong Kong SAR had about 2 percent higher TFP growth.

\section{CONCLUSION}

To summarize, this chapter has four main findings:

- Hong Kong SAR is roughly as competitive as the average OECD economy. Different measures tell slightly different stories. P-AC margins are generally higher in Hong Kong SAR, but P-MC margins are slightly lower. On almost all measures, Hong Kong SAR is neither the most nor the least competitive country in the 15-country sample.

\footnotetext{
${ }^{30}$ This estimate is based on the average P-MC margin of 0.33 for Hong Kong SAR at its 1986 industry mix from Table 7. The estimate for the OECD using the OLS version of the modified Roeger methodology was 0.36 . Estimates using other methodologies produced much higher P-MC margins; for the DHP and Roeger methodologies, the OLS estimates were 0.855 and 0.817 and the IV estimates were 0.540 and 0.653 , respectively.

${ }^{31}$ The estimate of labor as 80 percent variable is drawn fairly arbitrarily from Zitzewitz (1999), in which labor input in U.S. manufacturing industries is found to increase 0.8 percent in response to a 1 percent output increase in the short run.

${ }^{32}$ The importance of factor fixity underscores the need to analyze these issues using a structural model (Morrison, 1990), which would require much more data than was available for this project.

${ }^{33}$ These figures are from Young (1995).
} 
- Hong Kong SAR has become slightly less competitive in the last decade. The shift in industry mix to services has increased economy-wide average P-MC margins and value-added $\mathrm{P}-\mathrm{AC}$ margins. Within industries, gross output $\mathrm{P}-\mathrm{AC}$ margins have increased slightly in the last 10 years, as have value added $\mathrm{P}$-AC margins in manufacturing (Figure 3), while value-added P-AC margins have fallen in service industries.

- Margins are significantly more pro-cyclical in service industries compared to manufacturing. Since services are both the largest sector and have been rapidly increasing in importance in the last decade, overall margins should have also been becoming more pro-cyclical in Hong Kong SAR. Changes in margin cyclicality therefore would not be helpful in explaining any recent slowing of price adjustment.

- Imperfect competition can seriously distort traditional growth accounting exercises, biasing TFP growth measures downward, especially in rapidly growing economies. Correcting the labor shares requires not just estimating market power, but also understanding factor fixity. An alternative approach would be to estimate the production function directly using micro data. Neither of these was feasible given the data available for this project, but with more data, this could be a fruitful area for further study. 
Figure 3. Hong Kong SAR: P-AC Margins in Manufacturing and Service Sectors,1986-97

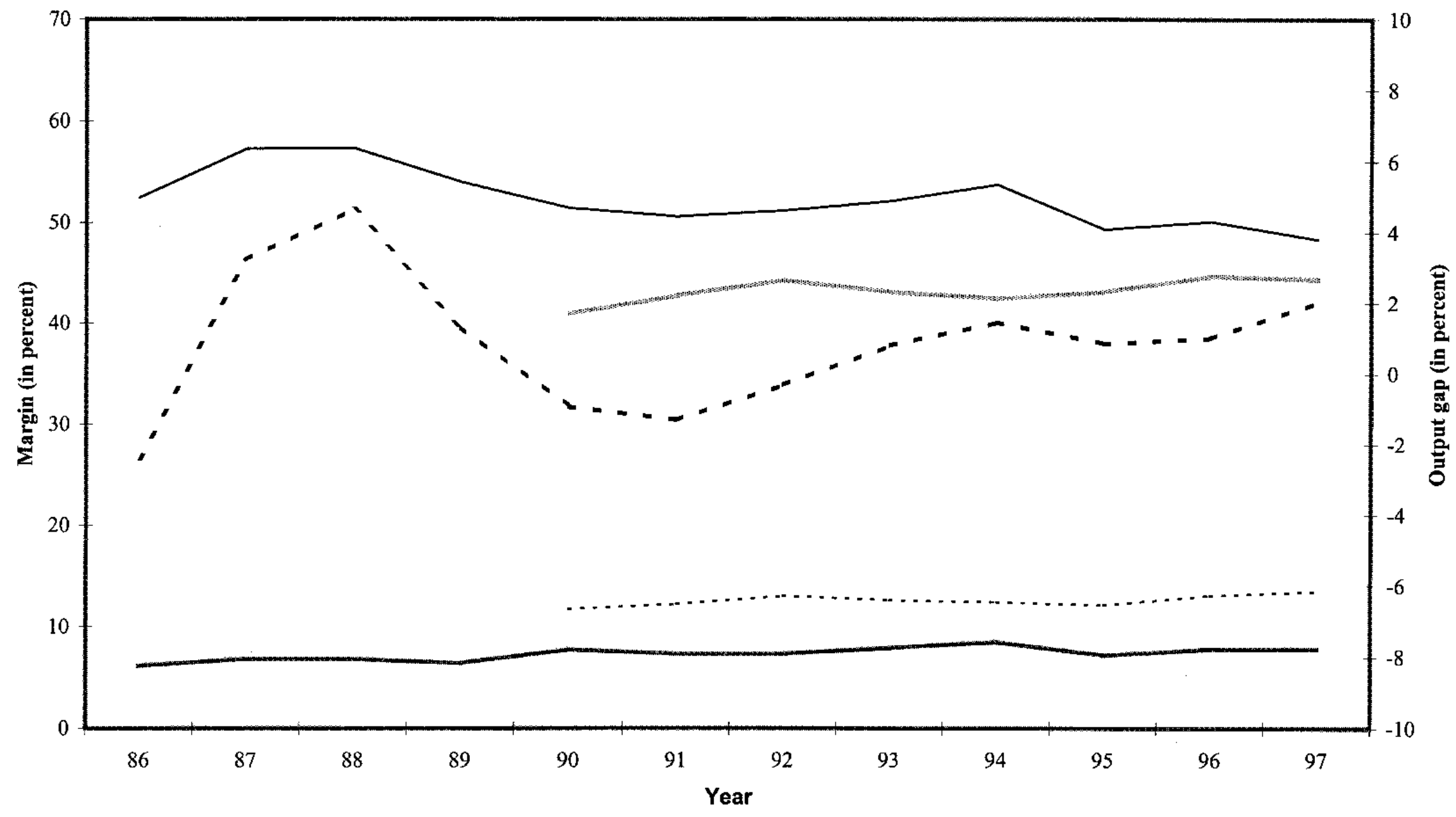




\section{References}

Barro, Robert J., 1998, “Notes on Growth Accounting,” NBER Working Paper No. 654 (Cambridge, Massachusetts: National Bureau of Economic Research).

Bils, Mark, 1987, "The Cyclical Behavior of Marginal Cost and Price," American Economic Review, Vol. 77 (December), pp. 838-55.

Bound, John, David A. Jaeger, and Regina M. Baker, 1995, "Problems with Instrumental Variables Estimation when the Correlation Between the Instruments and the Endogenous Explanatory Variable is Weak," Journal of the American Statistical Association, 90, pp. 443-50.

Dodsworth, John and Dubravko Mihaljek, 1997, Hong Kong SAR, China: Growth, Structural Change, and Economic Stability During the Transition, IMF Occasional Paper No. 52 (Washington: International Monetary Fund).

Domowitz Ian, R. Glenn Hubbard, and Bruce C. Petersen, 1986, "Business cycles and the relationship between concentration and price-cost margins," Rand Journal of Economics, 17 , pp. $1-17$.

Domowitz Ian, R. Glenn Hubbard, and Bruce C. Petersen, 1988, "Market Structure and Cyclical Fluctuations in U.S. Manufacturing," Review of Economics and Statistics, 70, pp. 55-66.

Ellison, Glenn, 1994, "Theories of Cartel Stability and the Joint Executive Committee," Rand Journal of Economics, 25, pp. 37-57.

Green, Edward J. and Robert H. Porter, 1984, "Non-cooperative collusion under imperfect price information," Econometrica, 52, pp. 87-100.

Hall, Robert E., 1988, "The Relation Between Price and Marginal Cost in U.S. Industry," Journal of Political Economy, 96, pp. 921-47.

1990, "Invariance properties of Solow's productivity residual," in

Growth/Productivity/Unemployment: Essays to Celebrate Bob Solow's Birthday, ed. by P. Diamond (Cambridge, Massachusetts: MIT Press).

Harrison, Ann E., 1994, "Productivity, imperfect competition, and trade reform," Journal of International Economics, 36, pp. 53-73.

Hausman, Jerry A., 1978, "Specification Tests in Econometrics," Econometrica, 46, pp. 1251-1272. 
Hsieh, Chang-Tai, 1997, "Measuring Technical Change," mimeo.

Morrison, Catherine, 1990, "Market Power, Economic Profitability, and Productivity Growth Measurement: An Integrated Structural Approach,” NBER Working Paper No. 355

(Cambridge, Massachusetts: National Bureau of Economic Research).

Nelson, Richard and Howard Pack, 1995, "The East Asian Growth Miracle and Modern Growth Theory," mimeo.

Oliveira Martins, Joaquim, Stefano Scarpetta, and Dirk Pilat, 1996, "Mark-up Ratios in Manufacturing Industries: Estimates for 14 OECD Countries," OECD Economics Department Working Paper No. 62 (Paris).

Rodrik, Dani, 1997, “TFPG Controversies, Institutions, and Economic Performance in East Asia," NBER Working Paper No. 514 (Cambridge, Massachusetts: National Bureau of Economic Research).

Roeger, Werner, 1995, "Can Imperfect Competition Explain the Difference Between Primal and Dual Productivity Measures? Estimates for U.S. Manufacturing," Journal of Political Economy, 103, pp. 316-330.

Rotemberg, Julio J., and Garth Saloner, 1986, “A Supergame-theoretic Model of Price Wars During Booms," American Economic Review, 76, pp. 390-407.

, and Michael Woodford, 1991, "Markups and the Business Cycle," NBER Macroeconomics Annual 1991 (Cambridge, Massachusetts: MIT Press).

1999 “The Cyclical Behavior of Prices and Costs," NBER Working Paper No. 609 (Cambridge, Massachusetts: National Bureau of Economic Research).

Sarel, Michael, 1997, “Growth and Productivity in ASEAN Countries,” IMF Working Paper 97/97 (Washington: International Monetary Fund).

Solow, Robert M., 1957, "Technical Change and the Aggregate Production Function," Review of Economics and Statistics, 39, pp. 312-320.

Young, Alwyn, 1995, "The Tyranny of Numbers: Confronting the Statistical Realities of the East Asian Growth Experience," Quarterly Journal of Economics, 110, pp. 641-680.

1998, "Paasche vs. Laspeyers: The Elasticity of Substitution and Bias in Measures of TFP Growth,” NBER Working Paper No. 663 (Cambridge, Massachusetts: National Bureau of Economic Research). 
Zitzewitz, Eric, 1999, "Real Exchange Rates, Trade Competition, Financial Pressure, and Productivity Growth in U.S. Manufacturing, 1958-92" (draft, Cambridge, Massachusetts: Massachusetts Institute of Technology). 


\section{Derivation of P-MC Measurement Methodologies}

All three methodologies (DHP 1988, Hall 1988, and Roeger 1995) start with a profit maximizing firm with a constant returns Cobb-Douglas production function facing a constant elasticity demand curve:

$$
\begin{aligned}
& Q=A L^{\alpha} \cdot K^{\beta} ; \alpha+\beta=1 \\
& Q=B P^{-\sigma} ; P Q=B^{-l / \sigma} \cdot Q^{l-l / \sigma} ; 1<\sigma<\infty
\end{aligned}
$$

where $\mathrm{P}, \mathrm{Q}, \mathrm{L}, \mathrm{K}$ and price, quantity, and labor and capital inputs, respectively. There are no fixed or adjustment costs. Firms maximize profits given factor costs $\mathrm{W}$ and $\mathrm{R}$.

$$
\pi=P Q-W L-R K
$$

The first order conditions yield the following relationships:

$$
\begin{aligned}
& P / M C=P / M R=(1-1 / \sigma)^{-1}=\mu \\
& W L / P Q=a=\alpha \cdot(1-1 / \sigma)=\alpha / \mu
\end{aligned}
$$

where a is the observed labor share. The expression for the change in the Solow residual (dTFP) is:

$$
d T F P=d q-a \cdot d l-(1-a) \cdot d k=(\mu-1) \cdot a \cdot(d l-d k)+d(\ln A)
$$

where lower case letters indicate logarithms. This equation comes from using the production function to substitute for $\mathrm{dq}$ and then $u \operatorname{sing} \alpha=\mathrm{a} \cdot \mu$ to remove $\alpha$. Adding $\mathrm{a} \cdot(\mathrm{dl}-\mathrm{dk})$ to both sides yields:

$$
d q-d k=\mu \cdot a \cdot(d l-d k)+d(\ln A)
$$

which can be estimated to yield an estimate of $\mu$, treating the change in productivity (ln A) as an error term. Since the change in the output-capital ratio is likely to be correlated with the change in productivity, the factors that affect industry demand (B) are used as instrumental variables since they should be correlated with $\mathrm{d}(1-\mathrm{k})$ but not with productivity. This is the Hall (1988) methodology. It relies on the assumptions of constant returns to scale, the absence of labor fixity or adjustment costs, and the orthogonality of the demand instruments to productivity but not to the labor-capital ratio. ${ }^{1}$

\footnotetext{
${ }^{1}$ Hall (1988) points out that even when labor is partly fixed or hoarded or when returns to scale are nonconstant, the estimate for $\mu$ should still be unbiased under perfect competition. Under imperfect competition, however, $\mu$ would be a biased estimator of the markup if these assumptions were violated.
} 
The DHP (1988) method is closely related. The estimating equation is obtained by substituting the expression for a.(dl $-\mathrm{dk})$ implied by (A2) into (A1). This yields:

$$
d T F P=(\mu-1) / \mu \cdot(d q-d k)+(1 / \mu) \cdot d(\ln A)=\gamma \cdot(d q-d k)+(1-\eta) \cdot d(\ln A)
$$

where $\gamma=(\mathrm{P}-\mathrm{MC}) / \mathrm{P}=(\mu-1) / \mu$, i.e. the $\mathrm{P}-\mathrm{MC}$ margin. Like the Hall specification, this equation can be estimated using an demand instrument which affects the output-capital ratio but not productivity. An advantage of the DHP specification over the Hall specification is that demand instruments are likely to be more strongly correlated with changes in the outputcapital ratio than with changes in the labor-capital ratio, giving an IV estimation using the DHP methodology more power.

Roeger (1995) takes a different approach, eliminating the productivity term by taking the difference of the primal (quantity-based) and dual (price-based) Solow residuals:

$$
\begin{aligned}
& d T F P-d T F P-D=(d q+d p)-a \cdot(d l+d w)-(1-a) \cdot(d k+d r) \\
& d T F P-D=-d p-a \cdot d w-(1-a) \cdot d r
\end{aligned}
$$

With a constant markup, the change in price will reflect the change in factor prices and the growth in productivity.

$$
d p=\alpha \cdot d w+(1-\alpha) \cdot d r-d(\ln A)
$$

Substituting for $\alpha$ yields

$$
d T F P-D=(\mu-1) \cdot a \cdot(d r-d w)+d(\ln A)
$$

which implies that

$$
d T F P-d T F P-D=(\mu-1) \cdot a \cdot[(d l+d w)-(d k+d r)]
$$

Equations (A4) and (A5) can be manipulated in the spirit of the DHP methodology to yield

$$
(d q+d p)-a \cdot(d l+d w)-(1-a) \cdot(d k+d r)=(\mu-1) / \mu \cdot[(d q+d p)-(d k+d r)]
$$

This yields a direct estimate for the P-MC margin $\gamma=(\mathrm{P}-\mathrm{MC}) / \mathrm{P}=(\mu-1) / \mu$. Roeger argues that since this equation omits the productivity term, it can be estimated via OLS without using demand instruments. Hausman (1978) tests in Table 4 support this assertion for U.S. data, but not for OECD data, suggesting that at least in the OECD data, one of the assumptions made by Roeger (e.g., no adjustment costs, constant returns to scale) is violated. 
Table 1, Results for Detailed Hong Kong SAR Industries

\begin{tabular}{|c|c|c|c|c|c|c|c|c|}
\hline & OECD & & & & & $\mathrm{Cyc}$ & joality & \\
\hline & ISDB & & $\therefore \quad \mathrm{P}-\mathrm{AC}$ & margins & Value a & Ided & Gross 0 & tput \\
\hline HKSIC & Code & Industry name & Value added & Gross oulput & coefr & s.e. & coeff & s.e. \\
\hline 311 & FOD & Food & 0.5 & 0.2 & -2.5 & 2.3 & -1.3 & 1.1 \\
\hline 313 & FOD & Beverage industries & 0.5 & 0.2 & 3.5 & 1.4 & 2.6 & 1.0 \\
\hline 314 & FOD & Tobacco manufactures & 0.8 & 0.3 & -0.7 & 0.9 & -2.7 & 1.4 \\
\hline 320 & TEX & Wearing apparel except footwear & 0.3 & 0.1 & -1.0 & 1.5 & -0.1 & 0.4 \\
\hline 323 & TEX & Leather and leather products, except footwear and wearing apparel & 0.4 & 0.1 & 0.7 & 1.4 & -0.1 & 0.4 \\
\hline 324 & TEX & Footwear, except rubber, plastic and wooden footwear & 0.2 & 0.1 & -6.9 & 2.4 & -2.0 & 0.5 \\
\hline 325 & TEX & Textiles & 0.4 & 0.1 & .2 .7 & 1.3 & -0.6 & 0.5 \\
\hline 331 & WOD & Wood and cork products except furniture & 0.4 & 0.1 & 1.4 & 2.2 & 0.3 & 0.6 \\
\hline 332 & WOD & Furniture and fixtures, except primarily of metal & 0.3 & 0.1 & -5.0 & 2.3 & -2.2 & 1.0 \\
\hline 341 & PAP & Paper and paper products & 0.4 & 0.1 & -0.1 & 1.7 & 0.2 & 0.8 \\
\hline 342 & PAP & Printing, publishing and aflied incustries & 0.4 & 0.2 & 2.6 & 2.9 & 1.6 & 1.5 \\
\hline 351 & CHE & Chemicals and chemical products & 0.5 & 0.1 & -1.3 & 2.9 & -0.7 & 1.7 \\
\hline 353 & CHE & Products of petroleum and coal & 0.7 & 0.3 & 2.2 & 4.2 & $-\$ .0$ & 2.7 \\
\hline 355 & $\mathrm{CHE}$ & Rubber products & 0.4 & 0.2 & -3.5 & 2.0 & -1.9 & 0.7 \\
\hline 356. & CHE & Plastic products & 0.4 & 0.1 & -2.4 & 1.3 & -1.1 & 0.9 \\
\hline 36 & MNM & Nonmetallic mineral products, except products of petroleum and coal & 0.6 & 0.1 & -6.4 & 2.6 & -2.4 & 0.9 \\
\hline 37 & BMI & Basic metal industries & 0.5 & 0.1 & -2.5 & 3.4 & -0.8 & 0.8 \\
\hline 380 & BMA & Fabricated metal products, except machinery and equipment & 0.4 & 0.1 & 2.7 & 0.7 & 1.0 & 0.7 \\
\hline 382 & MIO & Office, accounting and computing machinery & 0.6 & 0.1 & -3.2 & 1.6 & -1.1 & 0.6 \\
\hline 383 & MIO & Radio, television \& communication equipment and apparatus & 0.5 & 0.1 & -4.7 & 2.2 & -4.3 & 1.8 \\
\hline 384 & MEL & Electronic parts and components & 0.5 & 0.2 & 4.1 & 2.2 & 2.9 & 1.3 \\
\hline 385 & MEL & Electrical appliances \& houseware and electronic toys & 0.6 & 0.2 & 3.3 & 3.0 & 2.3 & 1.5 \\
\hline 386 & MAI & Machincry, equipment, apparatus, parts and components, n.e.c. & 0.4 & 0.2 & 0.5 & 1.1 & 0.4 & 0.6 \\
\hline 388 & MTR & Transport equipment & 0.3 & 0.2 & 0.8 & 1.2 & 0.4 & 0.8 \\
\hline 389 & MIO & Professional \& scientific, measuring \& controlling equipment, n.e.c., and photogr & 0.5 & 0.1 & 2.5 & 1.0 & -0.2 & 0.3 \\
\hline 39 & MOT & Manufacturing industries, n.e.c. & 0.4 & 0.1 & 3.9 & 1,3 & 1.4 & 0.4 \\
\hline 511 & CST & New construction works - Pre-erection works at construction sites & 0.2 & 0.1 & 5.3 & 3.1 & -1.2 & 0.8 \\
\hline 521 & CST & New construction works - Architectural and civil engineering work at construction & 0.2 & 0.1 & 1.5 & 1.6 & 0.2 & 0.5 \\
\hline 529 & $\mathrm{CST}$ & New construction works - Miscellaneous new construction works & 0.2 & 0.1 & 1.0 & 1.2 & 0.8 & 0.5 \\
\hline 531 & CST & Decoration, repair and maintenance & 0.2 & 0.1 & 1.2 & 1.3 & -0.1 & 0.3 \\
\hline 541 & CST & Special trades - Erection and general finishing & 0.2 & 0.1 & 0.3 & 1.1 & -0.1 & 0.5 \\
\hline 551 & CST & Special trades - Electrical and mechanical fitting & 0.2 & 0.1 & 1.0 & 1.6 & 0.8 & 0.5 \\
\hline 561 & CST & Special trades - Gas and water fitting & 0.2 & 0.1 & 1.9 & 1.4 & 0.8 & 0.7 \\
\hline 591 & $\operatorname{CST}$ & Special trades - Miscellaneous & 0.2 & 0.1 & 1.8 & 2.4 & 1.0 & 1.3 \\
\hline 61 & RWH & Total Wholesale & 0.5 & 0.0 & 0.1 & 0.3 & 0.0 & 0.0 \\
\hline 6111 & RWH & Food, alcoholic drinks and tobacco & 0.4 & 0.0 & 0.0 & 0.6 & 0.0 & 0.0 \\
\hline 6113 & $\mathrm{RWH}$ & Fuel & 0.5 & 0.0 & 0.4 & 0.4 & 0.1 & 0.1 \\
\hline 6114 & RWH & Clothing, footwear and allied products & 0.6 & 0.1 & -0.1 & 0.9 & 0.0 & 0.2 \\
\hline 6115 & RWH & Other durable goods and consumer goods, n.e.c. & 0.5 & 0.0 & -0.1 & 0.7 & 0.0 & 0.1 \\
\hline 6116 & RWH & Machinery, equipment and parts & 0.4 & 0.0 & -0.6 & 2.8 & 0.3 & 0.3 \\
\hline 6117 & RWH & Transport equipment & 0.5 & 0.0 & 0.9 & 1.7 & -0.2 & 0.2 \\
\hline 6121 & RWH & Raw materials and semi-manufactures & 0.6 & 0.0 & 0.2 & 0.7 & 0.2 & 0.1 \\
\hline 6122 & RWH & General commodities & 0.4 & 0.1 & 0.5 & 1.6 & -0.1 & 0.2 \\
\hline 62 & RWH & Total retail & 0.5 & 0.1 & 0.8 & 0.2 & 0.2 & 0.0 \\
\hline 6211 & RWH & Food, alcoholic drinks and tobacco & 0.5 & 0.1 & 0.2 & 0.4 & 0.0 & 0.1 \\
\hline 6213 & RWH & Fuel & 0.3 & 0.0 & 0.1 & 0.6 & 0.0 & 0.0 \\
\hline 6214 & RWH & Clothing, footwear and allied products & 0.4 & 0.1 & 1.4 & 0.4 & 0.4 & 0.1 \\
\hline 6215 & RWH & Other durable goods and consumer goods, n.e.c. & 0.5 & 0.1 & 0.7 & 0.3 & 0.1 & 0.1 \\
\hline 6216 & RWH & Transport equiptnent & 0.6 & 0.1 & 0.4 & 1.9 & 0.3 & 0.3 \\
\hline 63 & RWH & Total Import/Export & 0.6 & 0.1 & 0.5 & 0,1 & 0.0 & 0.0 \\
\hline 6311 & RWH & Food, alcoholic drinks and tobacco & 0.6 & 0.0 & 0.7 & 0.5 & 0.0 & 0.1 \\
\hline 6313 & RWH & Fuel & 0.8 & 0.1 & 1.7 & 0.6 & 0.9 & 0.2 \\
\hline 6314 & RWH & Clothing, footwear and allied products & 0.6 & 0.1 & 0.0 & 0.5 & 0.0 & 0.1 \\
\hline 6315 & RWH & Other durable goods and consumer goods, n.e.c. & 0.6 & 0.1 & 0.6 & 0.3 & 0.1 & 0.1 \\
\hline 6316 & RWH & Machinery, equipment and parts & 0.5 & 0.1 & 0.2 & 0.7 & -0.1 & 0.1 \\
\hline 6317 & RWH & Transport equipment & 0.6 & 0.0 & -2.0 & 2.0 & -0.1 & 0.3 \\
\hline 6321 & RWH & Raw materials and semi-manufactures & 0.6 & 0.0 & 0.5 & 0.3 & 0.1 & 0.1 \\
\hline 6322 & RWII & General commodities & 0.5 & 0.0 & 0.2 & 0.9 & -0.1 & 0.1 \\
\hline 6411 & HOT & Chinese restaurants & 0.2 & 0.1 & 1.2 & 0.5 & 0.4 & 0.2 \\
\hline 6412 & HOT & Restaurants, other than Chinese restaurants & 0.2 & 0.1 & 1,1 & 0.3 & 0.5 & 0.1 \\
\hline 6413 & HOT & Fast food shops & 0.3 & 0.1 & -0.5 & 0.5 & -0.2 & 0.2 \\
\hline 6414 & HOT & Bars & 0.2 & 0.1 & 1.7 & 0.7 & 0.8 & 0.3 \\
\hline 6415 & HOT & Eating and drinking places, n.e.c. & 0.4 & 0.1 & 0.9 & 0.9 & 0.4 & 0.4 \\
\hline 65 & HOT & Total Hotels/boarding houses & 0.5 & 0.3 & 0.9 & 0.8 & 0.8 & 0.6 \\
\hline 6511 & HOT & Hotels & 0.5 & 0.3 & 0.9 & 0.8 & 0.8 & 0.7 \\
\hline 6512 & HOT & Boarding houses & 0.5 & 0.3 & 0.3 & 0.4 & 0.2 & 0.5 \\
\hline 711 & TAS & Land passenger transport & 0.6 & 0.4 & 0.6 & 0.2 & -0.2 & 0.5 \\
\hline 712 & TAS & Land freight transport & 0.5 & 0.3 & 0.5 & 0.3 & 0.3 & 0.3 \\
\hline 713 & TAS & Supporting services to land transport & 0.7 & 0.3 & 0.0 & 0.2 & -1.1 & 0.5 \\
\hline 714 & TAS & Occan and coastal water transport & 0.6 & 0.2 & 1.3 & 0.5 & 0.6 & 0.6 \\
\hline 715 & TAS & Inland water transport & 0.5 & 0.2 & -0.1 & 0.4 & 0.1 & 0.4 \\
\hline 716 & TAS & Supporting services to water transport & 0.5 & 0.2 & 0.5 & 0.2 & -0.1 & 0.1 \\
\hline 717 & TAS & Air transport & 0.5 & 0.2 & 3.3 & 0.5 & 2.5 & 0.3 \\
\hline 718 & TAS & Services incidental to transport & 0.3 & 0.0 & -0.2 & 0.5 & 0.0 & 0.1 \\
\hline 831 & RES & Real estate development, leasing, brokerage \& maintenance management & 0.9 & 0.8 & 0.6 & 0.3 & 1.4 & 0.4 \\
\hline 8311 & RES & Real estate development and /or leasing & 1.0 & 0.9 & 0.1 & 0.1 & 0.7 & 0.2 \\
\hline 8314 & RES & Real estate maintenance management & 0.2 & 0.1 & 1.4 & 1.7 & 0,9 & 0.8 \\
\hline 8315 & RES & Real estate brokerage and agency & 0.3 & 0.2 & -2.2 & 2.0 & -1.7 & 1.9 \\
\hline 832 & RES & Business services & $\ldots$ & $\ldots$ & $\ldots$ & $\ldots$ & $\cdots$ & $\ldots$ \\
\hline 8334 & RES & Architectural, surveying \& project engineering & 0.2 & 0.1 & -0.6 & 0.6 & -0.6 & 0.4 \\
\hline 833401 & RES & Architectural design & 0.2 & 0.1 & 1.5 & 1.6 & 0.4 & 1.0 \\
\hline 833402 & RES & Real estate surveying, valuation and consultancy & 0.2 & 0.2 & 0.6 & 1.7 & 0.7 & 1.2 \\
\hline 833403 & RES & Structural enginecring & 0.3 & 0.2 & 3.2 & 5.7 & 1.0 & 3.6 \\
\hline 833404 & RES & Building services engineering & 0.2 & 0.1 & 0.2 & 1.3 & -0.3 & 1.1 \\
\hline 833405 & RES & Civil and geotechnical engineering & 0.2 & 0.1 & -5.4 & 1.7 & -3.3 & 1.0 \\
\hline 833406 & RES & Architectural design and structural engineering & 0.2 & 0.1 & -2.2 & 3.7 & -1.0 & 2.4 \\
\hline 833407 & RES & Combination of preceding services & 0.2 & 0.1 & -1.2 & 0.9 & -1.2 & 0.5 \\
\hline
\end{tabular}


Table 2. Shift in Industry mix in Hong Kong SAR, 1986-97

(Percent of GDP, current prices)

\begin{tabular}{lccc}
\hline Industry & 1986 & 1997 & Change \\
\hline Manufacturing & 22.6 & 6.5 & -16.1 \\
Food, beverages, and tobacco & 1.5 & 0.6 & -0.9 \\
Textiles, apparel and leather & 8.3 & 1.5 & -6.8 \\
Wood and wood products & 0.2 & 0.0 & -0.2 \\
Paper and paper products & 2.2 & 1.2 & -1.0 \\
Chemicals; rubber and plastic products & 1.9 & 0.4 & -1.6 \\
Nonmetallic minerals & 0.2 & 0.2 & 0.0 \\
Basic metal industries & 0.2 & 0.1 & -0.1 \\
Fabricated metal, machinery and equipment & 7.3 & 2.2 & -5.1 \\
$\quad$ Fabricated metal products & 1.4 & 0.3 & -1.1 \\
$\quad$ Agricultural and industrial machinery & 1.5 & 0.5 & -1.0 \\
Office equipment and instruments & 2.7 & 0.6 & -2.1 \\
$\quad$ Electrical goods & 1.1 & 0.6 & -0.5 \\
$\quad$ Transport equipment & 0.6 & 0.3 & -0.4 \\
Other manufacturing industries & 0.8 & 0.2 & -0.6 \\
& & & \\
Service industries studied & 38.8 & 47.8 & +9.0 \\
Construction & 4.8 & 5.8 & +1.0 \\
Wholesale and retail trade & 18.2 & 21.9 & +3.7 \\
Restaurants and hotels & 4.1 & 4.2 & +0.1 \\
Transportation & 5.5 & 5.7 & +0.2 \\
Real estate & 6.2 & 10.2 & +4.0 \\
& & & \\
Total for all industries studied & 61.4 & 54.3 & -7.1 \\
\hline Sources: & & &
\end{tabular}

Sources: Hong Kong Census and Statistical Department; and staff estimates.

Note: GDP shares for individual manufacturing industries in 1986 are estimated using 1990 data. The 1986 figure for total manufacturing not estimated. 
Table 3. Hong Kong SAR: Average P-AC Margins by Country

(Percent)

\begin{tabular}{lccccc}
\hline & \multicolumn{2}{c}{ Value Added } & & \multicolumn{2}{c}{ Gross Output } \\
\cline { 2 - 3 } \cline { 5 - 6 } \cline { 5 - 6 } Hong Kong SAR & 43.2 & 55.1 & & 12.6 & 8.3 \\
Australia & 40.3 & 58.5 & & 14.0 & N.A. \\
Belgium & 30.0 & 49.0 & & 9.5 & N.A. \\
Canada & 32.9 & 44.0 & & 11.1 & N.A. \\
Denmark & 29.0 & 53.1 & & 10.5 & N.A. \\
Finland & 38.9 & 45.6 & & 13.5 & N.A. \\
France & 35.0 & 42.9 & & 13.3 & N.A. \\
Germany & 32.4 & 36.9 & & 11.6 & N.A. \\
Italy & 43.1 & 64.7 & & 15.3 & N.A. \\
Japan & 48.7 & 41.5 & & 16.1 & N.A. \\
Netherlands & 34.7 & 48.7 & & 11.0 & N.A. \\
Norway & 27.5 & 53.9 & & 7.9 & N.A. \\
Sweden & 29.3 & 41.5 & & 9.1 & N.A. \\
United Kingdom & 24.0 & 46.8 & & 7.7 & N.A. \\
United States & 29.8 & 53.0 & & 10.6 & N.A. \\
Hong Kong SAR's rank & 14 & & & & 10 \\
\hline
\end{tabular}

Sources: Hong Kong Census and Statistical Department; and staff estimates.

Notes:

1. Services includes construction, wholesale-retail trade, hotels-restaurants, transport, and real estate.

2. Averages shown are weighted by the denominator (value added or output, respectively).

3. A low rank number implies more competition. 
Table 4. Hong Kong SAR: Cyclicality and Trend of P-AC Margins, 1986-97

\begin{tabular}{|c|c|c|c|c|}
\hline & \multicolumn{2}{|c|}{ Cyclicality } & \multicolumn{2}{|c|}{ Trend } \\
\hline & Manufacturing & Services & Manufacturing & Services \\
\hline \multirow[t]{2}{*}{ Hong Kong SAR } & -0.429 & 0.777 & 0.225 & -0.721 \\
\hline & $(0.730)$ & $(0.110)$ & $(0.355)$ & $(0.051)$ \\
\hline \multirow[t]{2}{*}{ Australia } & 0.260 & 0.053 & 0.413 & -0.268 \\
\hline & $(0.173)$ & $(0.117)$ & $(0.116)$ & $(0.080)$ \\
\hline \multirow[t]{2}{*}{ Belgium } & 0.392 & 0.221 & -0.127 & 0.188 \\
\hline & $(0.223)$ & $(0.168)$ & $(0.167)$ & $(0.127)$ \\
\hline \multirow[t]{2}{*}{ Canada } & 0.822 & -0.142 & -0.379 & -0.944 \\
\hline & $(0.194)$ & $(0.108)$ & $(0.256)$ & $(0.146)$ \\
\hline \multirow[t]{2}{*}{ Denmark } & 0.498 & -0.137 & 1.402 & 0.004 \\
\hline & $(0.116)$ & $(0.159)$ & $(0.097)$ & $(0.129)$ \\
\hline \multirow[t]{2}{*}{ Finland } & 0.242 & 0.206 & 1.049 & 0.331 \\
\hline & $(0.104)$ & $(0.143)$ & $(0.216)$ & $(0.303)$ \\
\hline \multirow[t]{2}{*}{ France } & 1.126 & 0.250 & 0.014 & 0.000 \\
\hline & $(0.146)$ & $(0.112)$ & $(0.106)$ & $(0.078)$ \\
\hline \multirow[t]{2}{*}{ Germany } & 0.555 & 0.726 & -0.821 & -0.419 \\
\hline & $(0.103)$ & $(0.178)$ & $(0.082)$ & $(0.132)$ \\
\hline \multirow[t]{2}{*}{ Italy } & -0.117 & 0.039 & -0.180 & 0.225 \\
\hline & $(0.171)$ & $(0.259)$ & $(0.102)$ & $(0.155)$ \\
\hline \multirow[t]{2}{*}{ Japan } & 0.869 & 0.927 & -0.998 & -0.477 \\
\hline & $(0.087)$ & $(0.152)$ & $(0.060)$ & $(0.104)$ \\
\hline \multirow[t]{2}{*}{ Netherlands } & 1.174 & 0.180 & 1.046 & -0.042 \\
\hline & $(0.326)$ & $(0.290)$ & $(0.114)$ & $(0.100)$ \\
\hline \multirow[t]{2}{*}{ Norway } & -1.171 & 0.168 & 0.242 & -0.517 \\
\hline & $(1.188)$ & $(0.542)$ & $(0.816)$ & $(0.370)$ \\
\hline \multirow[t]{2}{*}{ Sweden } & -0.644 & -0.522 & -0.789 & -0.472 \\
\hline & $(0.234)$ & $(0.215)$ & $(0.283)$ & $(0.267)$ \\
\hline \multirow[t]{2}{*}{ United Kingdom } & 0.708 & 1.018 & 0.766 & 0.489 \\
\hline & $(0.121)$ & $(0.171)$ & $(0.152)$ & $(0.222)$ \\
\hline \multirow[t]{2}{*}{ United States } & 0.768 & -0.127 & 0.432 & -0.204 \\
\hline & $(0.164)$ & $(0.135)$ & $(0.084)$ & $(0.070)$ \\
\hline Hong Kong SAR's rank & 13 & 3 & 9 & 2 \\
\hline
\end{tabular}

Sources: Hong Kong Census and Statistical Department; and staff estimates.

Notes:

1. A low rank number implies more pro-cyclicality or increasing competition. 
Table 5. Hong Kong SAR: Average P-MC Margins for Manufacturing and Services (Estimated using the OLS version of the feasible Roeger method)

\begin{tabular}{lcc}
\hline & Manufacturing & Services \\
\hline Hong Kong SAR & 0.303 & 0.397 \\
Australia & $(0.012)$ & $(0.007)$ \\
& 0.341 & 0.352 \\
Belgium & $(0.069)$ & $(0.024)$ \\
& 0.402 & 0.389 \\
Canada & $(0.017)$ & $(0.026)$ \\
& 0.368 & 0.430 \\
Denmark & $(0.021)$ & $(0.021)$ \\
France & 0.346 & 0.448 \\
& $(0.009)$ & $(0.020)$ \\
Germany & 0.396 & 0.384 \\
& $(0.022)$ & $(0.023)$ \\
Italy & 0.387 & 0.324 \\
Netherlands & $(0.012)$ & $(0.023)$ \\
& 0.425 & 0.392 \\
Norway & $(0.020)$ & $(0.027)$ \\
& 0.400 & 0.377 \\
Sweden & $(0.015)$ & $(0.017)$ \\
& 0.407 & 0.391 \\
United Kingdom & $(0.014)$ & $(0.019)$ \\
& 0.405 & 0.426 \\
United States & $(0.022)$ & $(0.019)$ \\
& 0.366 & 0.276 \\
Hong Kong SAR' rank (out of 13) & $(0.018)$ & $(0.040)$ \\
\hline Sources: Hon Ko & 0.378 & 0.456 \\
& $(0.011)$ & $(0.014)$ \\
& & \\
& & 9 \\
\hline
\end{tabular}

Sources: Hong Kong Census and Statistical Department; and staff estimates.

Notes:

1. A low rank number implies more competition. 